Prepared in cooperation with the U.S. Fish and Wildlife Service

\title{
Historical and Potential Groundwater Drawdown in the Bruneau Area, Owyhee County, Southwestern Idaho
}

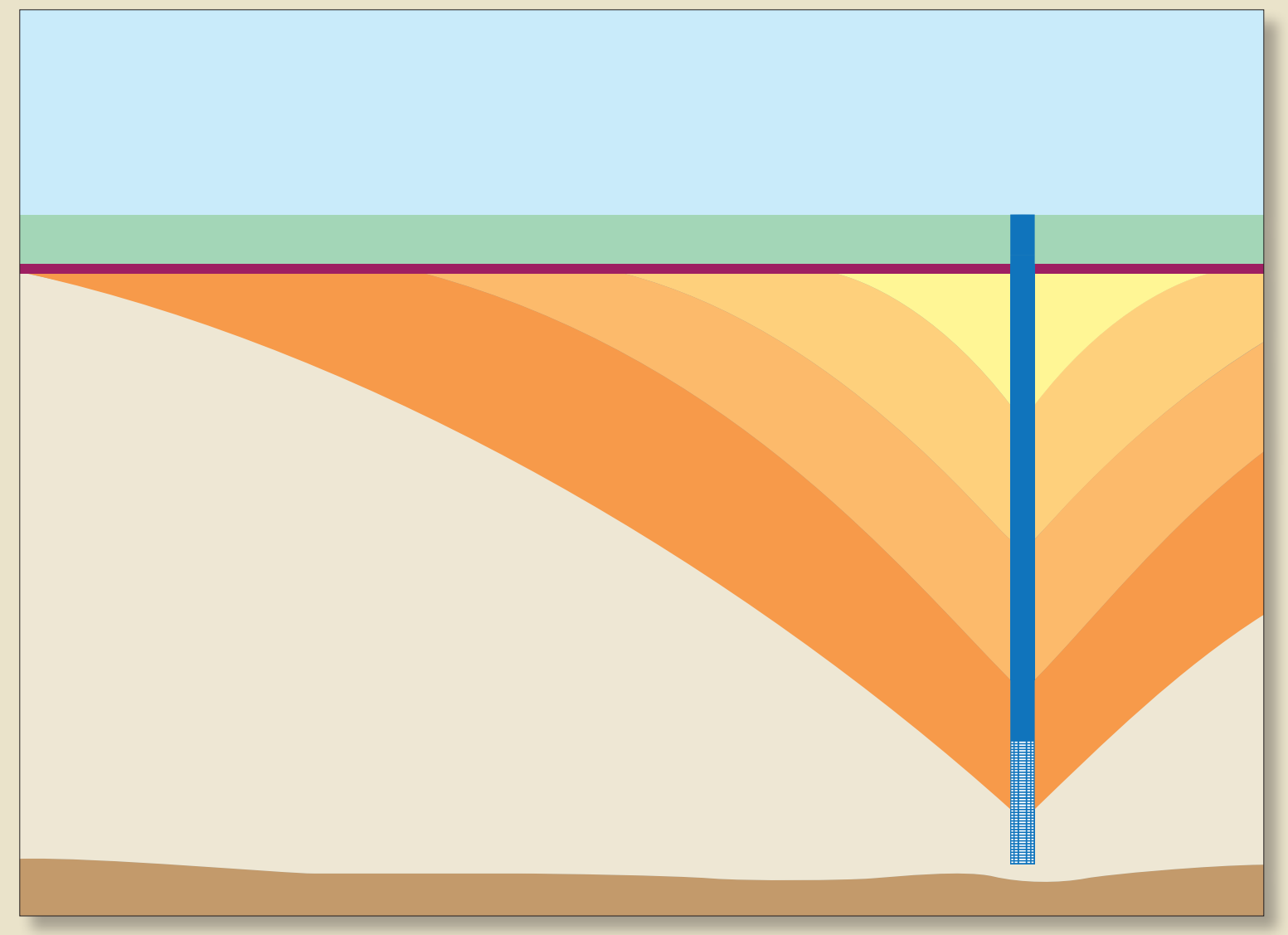

Scientific Investigations Report 2012-5119 
Cover: Diagrammatic representation of cones of depression produced by a pumping well. 


\section{Historical and Potential Groundwater Drawdown in the Bruneau Area, Owyhee County, Southwestern Idaho}

By Candice B. Adkins and James R. Bartolino

Prepared in cooperation with the U.S. Fish and Wildlife Service

Scientific Investigations Report 2012-5119 


\title{
U.S. Department of the Interior \\ KEN SALAZAR, Secretary \\ U.S. Geological Survey \\ Marcia K. McNutt, Director
}

\author{
U.S. Geological Survey, Reston, Virginia: 2012
}

For more information on the USGS - the Federal source for science about the Earth, its natural and living resources, natural hazards, and the environment, visit http://www.usgs.gov or call 1-888-ASK-USGS.

For an overview of USGS information products, including maps, imagery, and publications, visit http://www.usgs.gov/pubprod

To order this and other USGS information products, visit http://store.usgs.gov

Any use of trade, product, or firm names is for descriptive purposes only and does not imply endorsement by the U.S. Government.

Although this report is in the public domain, permission must be secured from the individual copyright owners to reproduce any copyrighted materials contained within this report.

Suggested citation:

Adkins, C.B., and Bartolino, J.R., 2012, Historical and potential groundwater drawdown in the Bruneau area, Owyhee County, southwestern Idaho: U.S. Geological Survey Scientific Investigations Report 2012-5119, 26 p. 


\section{Contents}

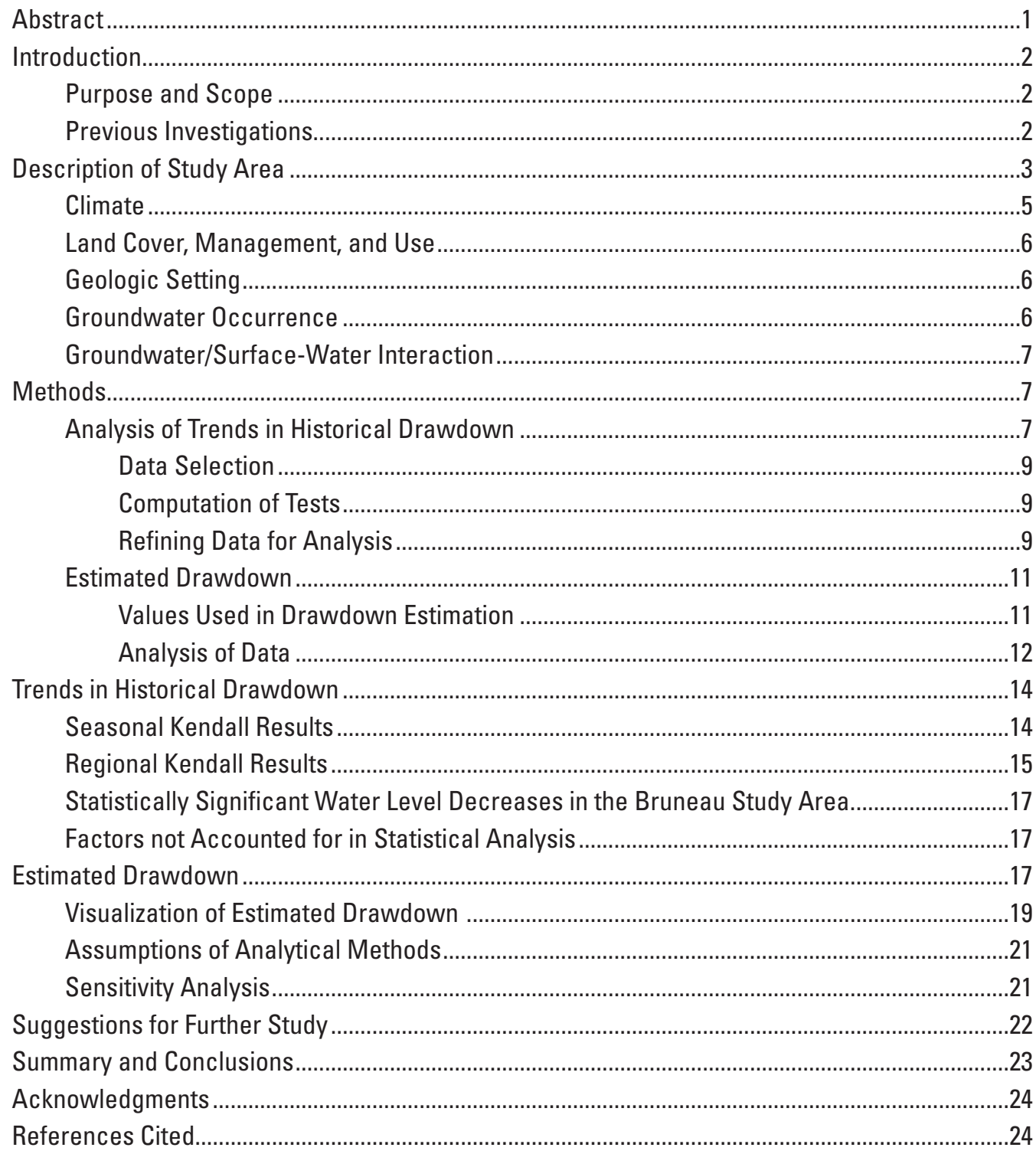

\section{Figures}

Figure 1. Map showing location of Bruneau study area, southwestern Idaho $\ldots \ldots \ldots \ldots \ldots$

Figure 2. Hydrograph showing seasonal fluctuations of water levels from well $07 \mathrm{~S} 06 \mathrm{E}$ 34BCA1, typical of seasonal fluctuation in response to groundwater pumping and

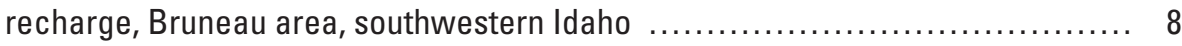

Figure 3. Map showing three locations representing the geothermal inflow stretch along

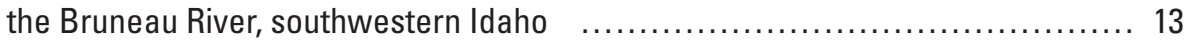

Figure 4. Graph showing slopes of trends of groundwater decline by monitoring well, generated by Seasonal Kendall test, Bruneau study area, southwestern Idaho . . 15 


\section{Figures-Continued}

Figure 5. Map showing groups of monitoring wells by regional topographic valley, Bruneau study area, southwestern Idaho

Figure 6. Graph showing slopes of trends of groundwater decline as calculated by the Regional Kendall test by depth of wells, Bruneau study area, southwestern Idaho 16

Figure 7. Map showing extent of cone of depression of 1 foot of drawdown with increasing time $(1,5,10$, and 20 years) assuming highest flow, mid-range transmissivity, and highest storativity values in the volcanic-rock aquifers, Bruneau area, southwestern Idaho

Figure 8. Diagrammatic representation of cones of depression produced by a pumping well 21

Figure 9. Map showing cones of depression based on different values of storativity 22

\section{Tables}

Table 1. National Weather Service and AgriMet stations near the Bruneau study area, southwestern Idaho.

Table 2. Summary of data from selected weather stations in and near the Bruneau study area, southwestern Idaho.

Table 3. Categories of wells for Regional Kendall analysis as suggested by U.S. Fish and Wildlife Service, March 2010.

Table 4. Location, record, and completion information for monitoring wells in topographically defined regions and weather stations that were used for statistical trend analysis, Bruneau study area, southwestern Idaho.

Table 5. Range of hydraulic parameters used in this study, Bruneau study area, southwestern Idaho.

Table 6. Extent of geothermal seeps and springs along the Bruneau River, southwestern Idaho.

Table 7. Results from Seasonal Kendall trend analysis of water levels in monitoring wells and weather stations, Bruneau study area, southwestern Idaho.

Table 8. Results from Regional Kendall trend analyses of water levels by categories, Bruneau study area, southwestern Idaho.

Table 9. Estimated distance of specified drawdowns and times in the sedimentary-rock aquifers, Bruneau study area, southwestern Idaho.

Table 10. Estimated distance of specified drawdowns and times in the volcanic-rock aquifers, Bruneau study area, southwestern Idaho. 


\section{Conversion Factors and Datums}

Conversion Factors

\begin{tabular}{|c|c|c|}
\hline Multiply & By & To obtain \\
\hline \multicolumn{3}{|c|}{ Length } \\
\hline inch (in.) & 25.4 & millimeter (mm) \\
\hline foot $(\mathrm{ft})$ & 0.3048 & meter (m) \\
\hline mile (mi) & 1.609 & kilometer (km) \\
\hline \multicolumn{3}{|c|}{ Area } \\
\hline acre & 4,047 & square meter $\left(\mathrm{m}^{2}\right)$ \\
\hline square mile $\left(\mathrm{mi}^{2}\right)$ & 2.590 & square kilometer $\left(\mathrm{km}^{2}\right)$ \\
\hline \multicolumn{3}{|c|}{ Volume } \\
\hline gallon (gal) & 0.003785 & cubic meter $\left(\mathrm{m}^{3}\right)$ \\
\hline cubic foot $\left(\mathrm{ft}^{3}\right)$ & 0.02832 & cubic meter $\left(\mathrm{m}^{3}\right)$ \\
\hline \multicolumn{3}{|c|}{ Flow rate } \\
\hline acre-foot per day (acre-ft/d) & 0.01427 & cubic meter per second $\left(\mathrm{m}^{3} / \mathrm{s}\right)$ \\
\hline acre-foot per year (acre-ft/yr) & 1,233 & cubic meter per year (m³/yr) \\
\hline \multicolumn{3}{|c|}{ Hydraulic conductivity } \\
\hline foot per day (ft/d) & 0.3048 & meter per day $(\mathrm{m} / \mathrm{d})$ \\
\hline \multicolumn{3}{|c|}{ Transmissivity* } \\
\hline foot squared per day $\left(\mathrm{ft}^{2} / \mathrm{d}\right)$ & 0.09290 & meter squared per day $\left(\mathrm{m}^{2} / \mathrm{d}\right)$ \\
\hline
\end{tabular}

Temperature in degrees Celsius $\left({ }^{\circ} \mathrm{C}\right)$ may be converted to degrees Fahrenheit $\left({ }^{\circ} \mathrm{F}\right)$ as follows:

$$
{ }^{\circ} \mathrm{F}=\left(1.8 x^{\circ} \mathrm{C}\right)+32 \text {. }
$$

*Transmissivity: The standard unit for transmissivity is cubic foot per day per square foot times foot of aquifer thickness $\left[\left(\mathrm{ft}^{3} / \mathrm{d}\right) / \mathrm{ft}^{2}\right] \mathrm{ft}$. In this report, the mathematically reduced form, foot squared per day $\left(\mathrm{ft}^{2} / \mathrm{d}\right)$, is used for convenience.

Datums

Horizontal coordinate information is referenced to the North American Datum of 1983 (NAD 83).

Vertical coordinate information is referenced to the North American Vertical Datum of 1988 (NAVD 88).

Elevation, as used in this report, refers to distance above the vertical datum. 
This page intentionally blank. 


\title{
Historical and Potential Groundwater Drawdown in the Bruneau Area, Owyhee County, Southwestern Idaho
}

\author{
By Candice B. Adkins and James R. Bartolino
}

\begin{abstract}
Geothermal seeps and springs in the Bruneau area in southwestern Idaho provide a vital but disappearing habitat for the Bruneau hot springsnail (Pyrgulopsis bruneauensis). In order to aid in conservation efforts, a two-part study was conducted (1) to determine trends in groundwater levels over time and (2) to simulate drawdown in aquifers that contribute to the geothermal seeps and springs along the Bruneau River.

Seasonal and Regional Kendall tests for trends were used to determine water-level trends over a 20-year monitoring (1990-2010) period. Seasonal Kendall tests were used to calculate trends in groundwater-levels in 22 monitoring wells and indicated statistically significant changes in water level with trends ranging from 0.21 to 1.0 feet per year. Regional Kendall tests were used to calculate drawdown in categories of wells based on five criteria (well depth, distance from Indian Bathtub Spring, geologic unit, regional topographic valley, and temperature). Results from Regional Kendall tests indicate that slope of the trend (in feet per year) increased as a function of well depth; trends in water level as a function of other categories did not exhibit an obvious pattern based on distance from Indian Bathtub Spring, geologic unit, topographic valley, or temperature.
\end{abstract}

\author{
Analytical solutions were used to simulate drawdown \\ and recovery in wells using the Theis equation and a range \\ of hydraulic parameters. Drawdown effects were determined \\ by changing the storativity, transmissivity, and flow values \\ over a hypothetical timeline. For example, estimates projected \\ that after 20 years of pumping (at an assumed storativity of \\ 0.002, a transmissivity of 980,000 feet squared per day, and \\ a flow of 100 acre-feet per year), 1 foot of drawdown in the \\ volcanic-rock aquifers would not be detected; however, other \\ estimates using the same time frame but different hydraulic \\ parameters (storativity of 0.001 , transmissivity of 13,000 feet \\ squared per day, and 610 acre-feet per year) determined 1 foot \\ of drawdown to be detected as far as 29 miles from the \\ hypothetical pumping well. A sensitivity analysis was \\ performed to determine the effect of changing one hydraulic \\ parameter while keeping the others constant. Many \\ assumptions had to be made about properties of the aquifer in \\ order to calculate effects of drawdown on geothermal seeps \\ and springs. These analyses estimate pumping effects over \\ time; the recovery of groundwater levels would likely take \\ significantly longer to observe than the effects from pumping.
}




\section{Introduction}

The Bruneau hot springsnail (Pyrgulopsis bruneauensis) is a small endangered gastropod found only in geothermal seeps and springs along a 5 mile (mi) length of the Bruneau River and a tributary, Hot Creek, in southwestern Idaho. The Bruneau hot springsnail inhabits exposed surfaces along geothermal seeps and springs in which water temperature ranges from 60.3 to $98.4^{\circ} \mathrm{F}$. The U.S. Fish and Wildlife Service (USFWS) has determined that the principal threat to the Bruneau hot springsnail is "the reduction and/or elimination of their geothermal springs habitat as a result of agricultural groundwater withdrawals” (U.S. Fish and Wildlife Service, 2007); furthermore, the species was listed as endangered by the USFWS in 1998 (Federal Register, 1998). Research was conducted to better understand declines in groundwater levels and their effects on springs and seeps in the Bruneau study area.

The regional geothermal aquifers that feed the seeps and springs along the Bruneau River are used for irrigation in the Bruneau, Little, and Sugar Valleys that compose the Bruneau study area (Berenbrock, 1993). Historical decreases in discharge from geothermal seeps and springs along the Bruneau River and Hot Creek have been associated with groundwater declines due to pumping of groundwater for irrigation (Berenbrock, 1993). This decrease in geothermal discharge has caused the hot springsnail habitat to decline (USFWS, 2007); the total number of geothermal seeps and springs located upstream of Hot Creek on the western side of the Bruneau River decreased from 84 (in 1991) to 54 (in 2010) (Hopper and Burak, 2011). Similarly, the number of springs decreased on the eastern side of the Bruneau River upstream of Hot Creek from 62 (in 1991) to 23 (in 2010) (Hopper and Burak, 2011).

A recovery plan adopted by the USFWS in 2002 for the Bruneau hot springsnail suggests implementing conservation measures to protect groundwater in the geothermal aquifer (U.S. Fish and Wildlife Service, 2002). A groundwater-flow model of the Bruneau study area could aid these stabilization efforts but an effort conducted by the U.S. Geological Survey (USGS) in the early 1990s to develop a model was unsuccessful because of a lack of data for this highly complex aquifer system (Berenbrock, 1993). However, information collected in previous studies can still be used to help guide future conservation efforts. This study incorporates previously collected data with statistical and analytical techniques to increase understanding of current groundwater conditions.

\section{Purpose and Scope}

In 2010, the USGS, in cooperation with the USFWS, conducted a two-part study to address concerns about recent groundwater trends and to help guide future groundwater conservation efforts. The first part of the study completed in 2010, analyzed groundwater levels in 22 wells over a 20-year period to determine trends over time. The second part of the study, completed in 2012, used analytical solutions of the Theis equation (Theis, 1935) to approximate the extent, timing, and magnitude of drawdown from continuous groundwater pumping by a hypothetical single well within the study area. These estimates required simplifications of, and assumptions about, actual conditions based on limited data. However, these estimates provide information on how pumping from wells in certain locations of the Bruneau area has affected spring flows.

This report describes methods, results, and conclusions about trends in groundwater drawdown from 1990 to 2010 and estimated future drawdown as determined by this study. Previous studies are used to substantiate findings from this report. Conclusions from this report and suggestions for future studies include determinations from both components of this study.

\section{Previous Investigations}

Several studies have been made on the occurrence, use, and chemistry of groundwater in and around the Brueanu study area. These studies have been supplemented by geological information from previous studies on the Bruneau Plateau and adjacent eastern Snake River Plain.

Early reports by Piper (1924) and Stearns and others (1937) examined groundwater resources and estimated annual withdrawal of groundwater from wells. Littleton and Crosthwaite (1957) identified multiple aquifer systems; artesian aquifers were suggested as sources for future water supply. The quantity and quality of water was estimated; chemical analyses of water samples revealed high sodium and fluoride concentrations in some groundwater (Littleton and Crosthwaite, 1957). Ralston and Chapman (1969) studied both availability and conditions of groundwater in northern Owyhee County.

An audio-magnetotelluric (AMT) survey conducted by Jackson (1974) examined resistivities along a cross section including the study area. Thermal fluids were speculated to rise along basement faults and then be transported laterally 
into permeable layers. Blackwell (1975) logged temperatures in 41 wells to determine a geothermal gradient and described heat flow for commercial geothermal development. This study produced temperature data, geothermal gradients, and heat flow data for wells in north-central Owyhee County, Idaho. Blackwell (1975) discovered that geothermal gradients are higher in the Bruneau area than in the neighboring areas around Grand View; variations in geothermal gradients were speculated to be due to higher heat flow from basement rocks or lateral heat transport by water.

Young and Whitehead (1975) inventoried and sampled 94 wells and springs in the Bruneau-Grand View area to assess the geothermal system and probable sources of recharge and their report described areal extent of the Bruneau geothermal system. As part of a follow-up study, Young and Lewis (1982) analyzed water from 12 wells and 9 springs in north-central Nevada and southwestern Idaho. Stable isotopes indicated that climate during recharge was $5-9{ }^{\circ} \mathrm{F}$ cooler than 1975 temperatures and carbon-14 dating indicated geothermal waters had an age of 18,000 to 25,000 years. Age dating suggested water in this area circulates for thousands to tens of thousands of years.

Moffat and Jones (1984) investigated sources of groundwater and surface water available in the Bruneau area, as well as agricultural demand for water resources, and concluded that the demand on water resources was higher than the sustainable amount of groundwater withdrawal. Chemical analyses were conducted on water samples from selected wells and results indicated that water from some wells exceeded the U.S. Environmental Protection Agency's recommended drinking water limits for dissolved solids, $\mathrm{pH}$, fluoride, chloride, or sulfate. Recharge was determined to be from precipitation, leakage from unlined canals, percolation of excess irrigation water, groundwater inflow across the southern boundary of the study area, upward leakage of water from the geothermal system, and downward leakage from the overlying perched system. Young and others (1990) described eight test holes and selected thermal-water wells for hydrologic monitoring. Data from their report included well-completion, lithologic, and gamma log information for the eight test holes. This report also included hydrographs of geothermal water springs as well as chemical and isotopic analyses of water from six of the eight test holes.

Berenbrock (1993) performed a groundwater resource investigation in the greater Bruneau area for the purpose of better understanding the habitat and groundwater available for the Bruneau hot springsnail. Groundwater resources were mapped and water use, areas of recharge, history of groundwater discharge, groundwater movement, and trends in water levels were discussed. A geothermal aquifer was identified throughout the region in both sedimentary and volcanic rocks. Four larger-scale cones of depression in the potentiometric surface were identified in both the sedimentary-rock and volcanic-rock aquifers and were attributed to pumping. Changes in spring discharge corresponded with changes in hydraulic head throughout the region. This report also included calculations of hydraulic properties of the aquifer (such as transmissivity and hydraulic conductivity, specific capacity, and storativity) as determined by aquifer tests.

Harrington and Bendixsen (1999) reviewed the hydrologic condition of the Grandview-Bruneau Groundwater Management Area and determined that the overall groundwater system was relatively stable. As part of a follow-up study, the Idaho Department of Water Resources (IDWR) reviewed data collected from 18 monitoring wells throughout the Grand View-Bruneau Groundwater Management Area (McVay, 2012). Water levels in monitoring wells were examined for changes over a 10-year time period (2000-2010) and 20-year time period (1990-2010). McVay (2012) concluded that groundwater levels declined in 16 of 17 wells over the 10-year time period and groundwater levels declined in 15 of 17 wells over the 20 -year time period. These wells showed seasonal fluctuation and exhibited declining groundwater levels at an average rate of 0.76 feet per year (ft/yr) from 2000 to 2010.

\section{Description of Study Area}

The Bruneau study area (fig. 1) is located in southwestern Idaho, near the towns of Bruneau and Grand View, about $65 \mathrm{mi}$ southeast of Boise. It is bounded by the Snake River to the north, the Owyhee Mountains and Chalk Hills to the west, the Jarbidge Mountains to the south, and the Bruneau Plateau to the east. The study area lies on the southern margin of the northwest-trending western Snake River Plain and on the northern margin of the Bruneau-Jarbidge eruptive center. Berenbrock (1993) defined the Bruneau study area as extending from $42^{\circ} 45^{\prime}$ latitude north to the Snake River and east from the drainage divide of Little Jacks Creek and Shoofly Creek to the drainage divide between the Bruneau River and Sailor Creek, an area of about 600 square miles $\left(\mathrm{mi}^{2}\right)$. 


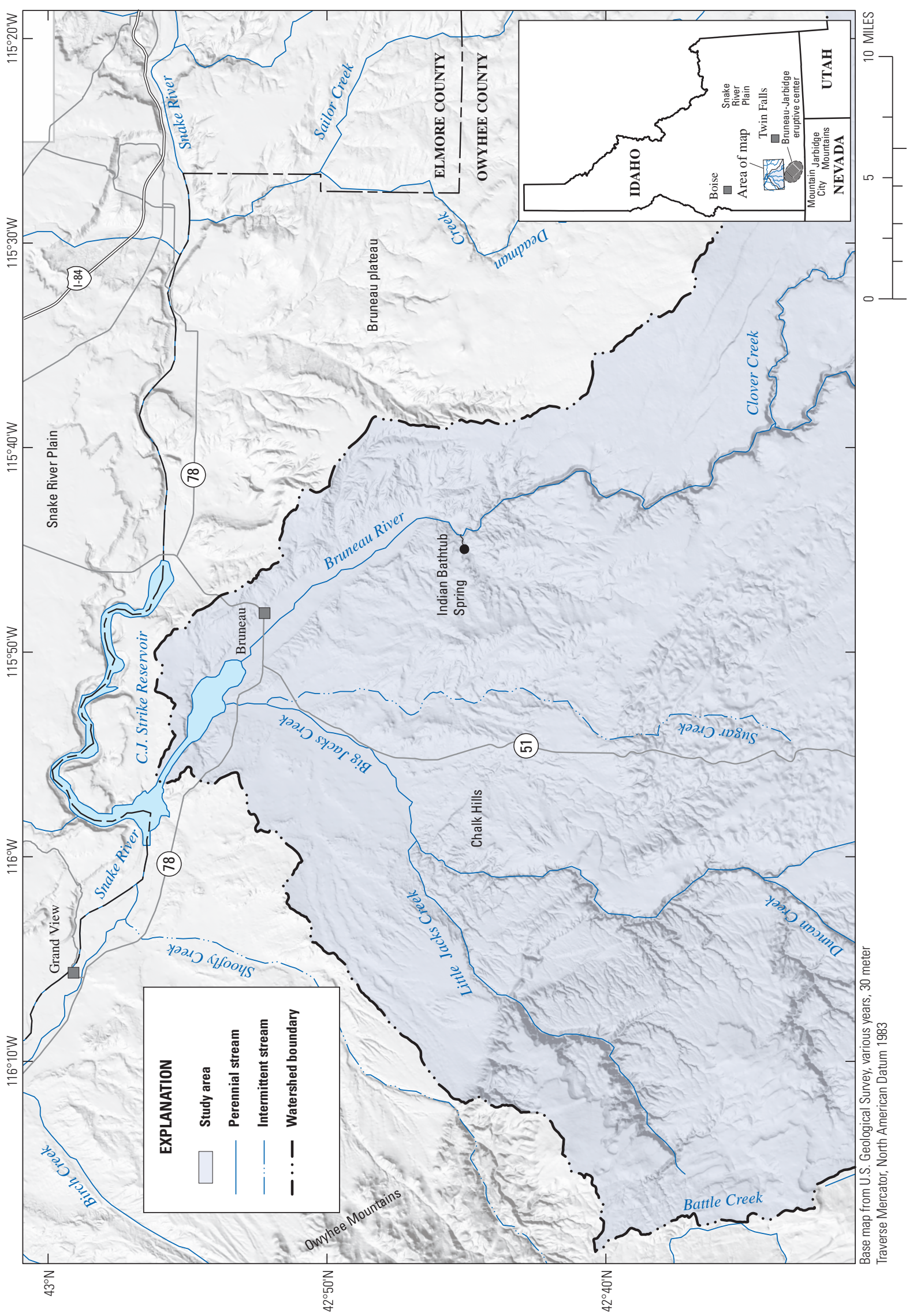

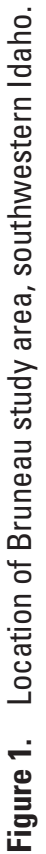




\section{Climate}

Most of the study area is classified as BSk under the modified Köppen climate classification system in which $\mathrm{B}$ indicates a dry climate with annual evaporation greater than precipitation; S specifies a semiarid steppe with annual precipitation ranging between 15 and 30 inches (in.); and $\mathrm{k}$ indicates a dry and cold climate with a mean annual temperature below $64^{\circ} \mathrm{F}$ (Critchfield, 1983; Godfrey, 2000; Peel and others, 2007). The National Weather Service (NWS) currently (2012) has four active weather stations within $25 \mathrm{mi}$ of the town of Bruneau: Bruneau, Mountain Home, Grand View 4 NW, and Glenns Ferry. An additional nine weather stations are either inactive, including the Mountain City, Nevada, station, or the NWS has not received any observation data (U.S. Department of Commerce, 2011). As of 2011, there were two active AgriMet stations located in or within 25 mi of the study area: Grand View (GDVI) and Glenns Ferry (GFRI) (Bureau of Reclamation, 2011). More information about these stations is provided in table 1.
The four active NWS stations provide sufficient data for calculation of long-term mean temperatures (table 2). Mean annual temperatures at the four stations ranged from $50.5^{\circ} \mathrm{F}$ at Mountain Home to $54.7^{\circ} \mathrm{F}$ at Bruneau (table 2). The coldest month in the area typically is January, with mean low temperatures ranging from $20.3^{\circ} \mathrm{F}$ at Glenns Ferry to $23.4^{\circ} \mathrm{F}$ at Bruneau. The warmest month typically is July, with mean high temperatures ranging from $93.2^{\circ} \mathrm{F}$ at Mountain Home to $96.0^{\circ} \mathrm{F}$ at Glenns Ferry. Mean first-freeze dates range from September 23 at Glenns Ferry to October 5 at Bruneau; mean last-freeze dates range from May 7 at Bruneau to May 19 at Glenns Ferry. Mean annual precipitation ranges from 6.91 in. at Grand View 4 NW to 9.98 in. at Mountain Home. July and August typically are the driest months; November, December, and January are the wettest (Western Regional Climate Center, 2011). The inactive Mountain City station provides historical precipitation and temperature data of the area upstream of the Bruneau study area; historical mean annual precipitation was 13.53 in. during the data-collection period.

Table 1. National Weather Service and AgriMet stations near the Bruneau study area, southwestern Idaho.

[L atitude and longitude in decimal degrees. Horizontal coordinate system is North American Datum of 1983; vertical coordinate information is North American Vertical Datum of 1988]

\begin{tabular}{|c|c|c|c|c|c|c|}
\hline \multirow{2}{*}{ Station name } & \multirow{2}{*}{$\begin{array}{c}\text { Station or } \\
\text { identification } \\
\text { No. }\end{array}$} & \multirow{2}{*}{$\begin{array}{c}\text { Elevation } \\
\text { (feet) }\end{array}$} & \multirow{2}{*}{$\begin{array}{c}\text { Latitude } \\
\text { (north) }\end{array}$} & \multirow{2}{*}{$\begin{array}{l}\text { Longitude } \\
\text { (west) }\end{array}$} & \multicolumn{2}{|c|}{ Dates in operation } \\
\hline & & & & & Starting date & Ending date \\
\hline \multicolumn{7}{|c|}{ National Weather Service stations ${ }^{1}$} \\
\hline Bruneau & 101195 & 2,530 & 42.88 & -115.80 & 01-01-37 & Present \\
\hline Glenns Ferry & 103631 & 2,466 & 42.93 & -115.32 & 08-01-48 & Present \\
\hline Grand View 4 NW & 103760 & 2,400 & 43.02 & -116.18 & 08-01-48 & Present \\
\hline Mountain Home & 106174 & 3,140 & 43.13 & -115.72 & 08-01-48 & Present \\
\hline Mountain City & 265392 & 5,620 & 41.78 & -115.97 & 02-11-55 & 11-30-99 \\
\hline \multicolumn{7}{|c|}{ AgriMet stations ${ }^{2}$} \\
\hline Glenns Ferry & GFRI & 3,025 & 42.87 & -115.35 & 04-13-93 & Present \\
\hline Grand View & GDVI & 2,580 & 42.91 & -116.06 & 02-10-93 & Present \\
\hline
\end{tabular}

${ }^{1}$ Data from Western Regional Climate Center (2011).

${ }^{2}$ Data from Bureau of Reclamation (2011).

Table 2. Summary of data from selected weather stations in and near the Bruneau study area, southwestern Idaho.

[Data from Western Regional Climate Center (2011). Summary values are through December 31, 2005, for active stations. Mean total precipitation includes melted snow. A bbreviations: ${ }^{\circ} \mathrm{F}$, degrees Fahrenheit; in., inch; ND, no data]

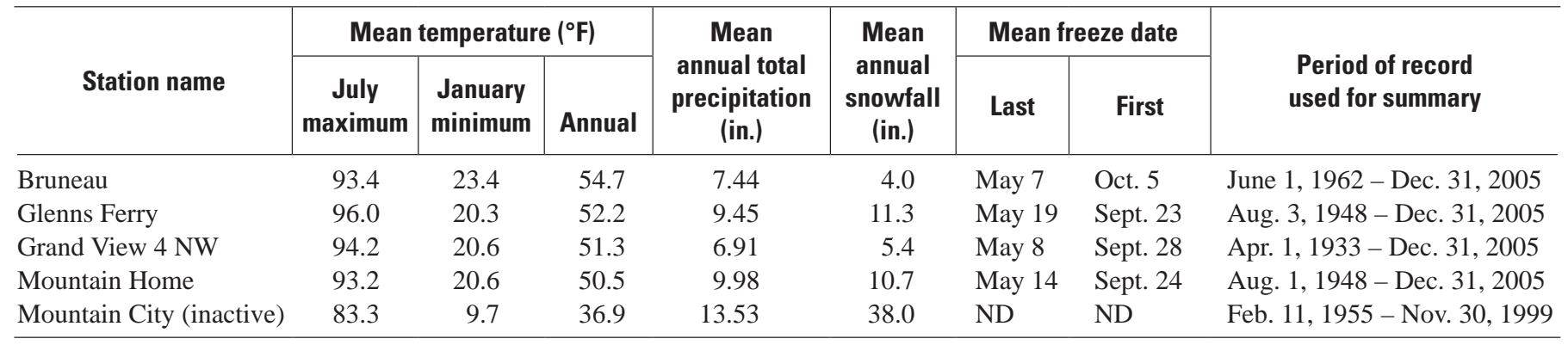




\section{Land Cover, Management, and Use}

The Bruneau study area lies within the Intermountain Sagebrush Province/Sagebrush Steppe ecosystem of the Bailey-Kuchler classification (Bureau of Land Management, 2009). By the Level IV ecoregion classification, land in the study area falls into two classes: valley bottoms are classified as Treasure Valley ecoregion and uplands are classified as Unwooded Alkaline Foothills ecoregion (McGrath and others, 2002).

Most of the land in the study area is federally owned and is under the control of the Bureau of Land Management, which leases the land for grazing. In the vicinity of Bruneau, much of the low-lying land along Little Jacks and Sugar Creeks and the Bruneau River is privately owned and under cultivation. Alfalfa is the major crop along with corn, oats, potatoes, dry beans, and sugar beets (National Agricultural Statistics Service, 2011). Irrigation water for these crops is mostly supplied by groundwater, although some land is irrigated by surface-water diversions.

The first European settlers in the Bruneau area arrived around 1870 to establish cattle ranches. Farming began in the 1880s with irrigation water diverted from streams and rivers in the area (Idaho State Historical Society, 1964, 1975). Currently (2012), three irrigation companies divert surface water for irrigation: Bruneau Buckaroo Cooperative Ditch Company, Hot Springs Ditch Company, and the South Side Bruneau Canal Company. Groundwater development began in 1896, and by 1922 slightly more than 100 flowing irrigation wells were in use (Berenbrock, 1993). In 1954, the use of groundwater for irrigation accelerated; by 1982, about 220 irrigation wells had been drilled (Berenbrock, 1993). This increase in pumping led to declines in groundwater levels and spring discharges, and in response, the Bruneau-Grand View Groundwater Management Area was established by the Idaho Department of Water Resources in 1982 (Idaho Department of Water Resources, 2011).

The main community in the study area is the unincorporated town of Bruneau. The Bruneau census county division (CCD) encompasses about the eastern one-third of Owyhee County, and it had a 2010 census population of 629 (U.S. Census Bureau, 2011).

\section{Geologic Setting}

The oldest rocks in or near the study area are rhyolitic ash-flow tuffs correlated to Eocene Challis Volcanics. These rocks are overlain by Miocene rhyolite flows of the Idavada Volcanics which, along with the faulting that created the western Snake River Plain, are related to the track of the Yellowstone hot spot. This volcanism transitioned to bimodal volcanism with the eruption of basaltic shield volcanoes and continued rhyolite flows. By Pliocene time, volcanism had completed the transition to basalt with the eruption of additional shield volcanoes and basalts erupted in a subaqueous environment beneath the paleo Lake Idaho (Jenks and others, 1998; Wood and Clemens, 2002).

Lake Idaho probably formed in the late Miocene as rhyolitic volcanism ended. At its greatest extent, Lake Idaho probably extended from the present city of Twin Falls, Idaho, to the present Idaho-Oregon border. As the lake subsided, it was filled with thick sequences of sediment interbedded with basalt, together forming the Idaho Group. This lake persisted into the Pleistocene, although its extent fluctuated with changes in climate and tectonism, causing cycles of erosion and redeposition of lake deposits. Lake Idaho was finally breached as the ancestral Snake River established its current course and tributary streams in the area formed. These post-Lake Idaho volcanic rocks and interbedded sediment associated with the through-flowing Snake River compose the Pleistocene Snake River Group. Deposits of Quaternary alluvium overlie the older rocks along streams and alluvial fans, and localized areas of eolian sediment are present (Malde and Powers, 1962; Jenks and others, 1998).

The area is heavily faulted, and most faults apparently occurred after Lake Idaho drained. Faults trend in two directions: (1) northwest-trending faults that parallel the western Snake River Plain, and (2) apparently older north- to northeast-trending faults that control the spatial distribution of most of the tributary valleys in the area, as well as some, if not most, of the springs (Jenks and others, 1998).

\section{Groundwater Occurrence}

Young and Whitehead (1975) defined two primary aquifer types in the study area based on lithology: sedimentary-rock aquifers and underlying volcanic-rock aquifers. Geothermal water occurs in both aquifer types. Sedimentary-rock aquifers are composed of unconsolidated and consolidated sediments and interbedded volcanic rocks of the Miocene to Pleistocene Idaho Group and Pleistocene Snake River Group. Although the Idaho Group sediments primarily are fine-grained sands, silts, and clays typical of lacustrine deposition, coarser grained sand and gravel units were deposited under deltaic or alluvial conditions as lake levels fluctuated (Young and Whitehead, 1975). Snake River Group sediments range from gravels deposited by the Snake River and its tributaries to fine-grained sediment deposited between lava flows. The sedimentary-rock aquifers are about 2,000 $\mathrm{ft}$ thick in the Bruneau study area. Interbedded fine- and coarse-grained sediment and volcanic rocks create confined or semiconfined conditions in the sedimentary rock aquifer and well yields vary considerably. 
Recharge to the sedimentary-rock aquifers probably is from infiltration of precipitation onto the surrounding Bruneau Plateau and Owyhee and Jarbidge Mountains (Young and Whitehead, 1975). Newton (1991) included the sedimentary-rock aquifers near Bruneau as part of the western Snake River Plain regional aquifer system.

The volcanic-rock aquifers are composed of the Pliocene Banbury Basalt of the Idaho Group underlain by Miocene rhyolite flows of the Idavada Volcanics, and they may be about 2,500 ft thick in the study area. Groundwater is under confined conditions with fine-grained sediments or dense volcanic rocks acting as confining beds; well yields range from poor to excellent. Recharge primarily is from infiltration of precipitation on volcanic-rock outcrops in the Owyhee and Jarbidge Mountains (Young and Whitehead, 1975).

Locally, unconsolidated Quaternary alluvium along stream channels yields water to wells and springs. The alluvium is less than $100 \mathrm{ft}$ thick and groundwater is under unconfined conditions. Recharge is from infiltration of precipitation, losing stream reaches, excess irrigation water, and possible upwelling of deeper groundwater (Berenbrock, 1993).

Many springs and wells in the study area produce geothermal water. Groundwater temperatures ranged from 59 to $109^{\circ} \mathrm{F}$ in the sedimentary-rock aquifers, and from 49 to $181^{\circ} \mathrm{F}$ in the volcanic rock aquifers; a sole temperature measurement from alluvium was $52^{\circ} \mathrm{F}$ (Young and Whitehead, 1975). Young and Whitehead (1975) concluded that volcanic rock aquifers were the source of geothermal water because of high water temperatures. Berenbrock (1993) stated that several lines of evidence presented by previous studies suggested that most of the springs in the study area discharge water from the volcanic-rock aquifers.

\section{Groundwater/Surface-Water Interaction}

Surface water in the Brueanu study area loses water to and gains water from groundwater. Spring discharge in the Bruneau study area provided about 10,100 acre feet per year (acre-ft/yr) prior to extensive groundwater development (Littleton and Crosthwaite, 1957) and geothermal seeps and springs along the Bruneau River still support an important ecological area. The cold-water aquifer receives recharge from infiltration of precipitation, streamflow, and applied irrigation water (Berenbrock, 1993). Due to the lack of data about the hydrologic connection between the cold-water and geothermal-water aquifers, we are currently unable to determine the interaction between surface water with the underlying geothermal aquifer.

Limited information is available about the quantity of groundwater recharge from surface water. It is difficult to locate areas where surface water may be recharging groundwater because no gain/loss studies have been conducted along the Bruneau River to date (2012). Limited information suggests that the majority of flow from Little and Big Jacks Creeks infiltrates to the groundwater system (Kjelstrom, 1986). Due to the uncertain connection between the geothermal aquifers and surface water, interactions between the two were not included in the estimated drawdown portion of this study.

\section{Methods}

\section{Analysis of Trends in Historical Drawdown}

Starting in 2010, the USGS, in cooperation with the USFWS, performed a statistical analysis of historical water-level data in the Bruneau study area to determine trends in groundwater levels between 1990 and 2010. Previous studies suggested that water levels had declined and that discharge from geothermal seeps and springs had decreased with time (Hopper and Burak, 2011; McVay, 2012). A statistical analysis was conducted to determine if there was a statistically significant change in water levels in recent history. A trend test was performed on water-level data from monitoring wells with ten or more years of data over the period of record. Water level data from selected wells were analyzed individually, and in groups recommended by USFWS in order to determine if groundwater levels had significantly declined over a 20 -year monitoring period.

Data were trend-tested using variations of the nonparametric Kendall test, a statistical test for trends over time (Helsel and Hirsch, 2002). Kendall tests generally are used to determine whether data (in this case, water levels) demonstrate a monotonic trend during a given time period. The test computes a Kendall's tau nonparametric correlation coefficient as its test of significance, along with a slope and intercept indicating the direction and magnitude of the trend (Helsel and others, 2006). A positive slope indicates increasing depth to water, or increasing drawdown. 
Two methods of Kendall tests were used for this study: a Seasonal Kendall test for individual wells and a Regional Kendall test for multiple wells in one category. Monitoring wells in the area respond seasonally to groundwater pumping and recharge (McVay, 2012); the effect of seasonal irrigation pumping is evident in hydrographs of individual wells (ig. 2). To compensate for this seasonal variation and to better discern the trend in water levels over time, a Seasonal Kendall test was used. Seasonal Kendall tests correct for seasonality by performing a Kendall test on each season separately (defined here as irrigation and non-irrigation season, or approximately May-September and October-April) and then combining the results to determine the overall trend in the data, if any. Individual wells were trend-tested using a Seasonal Kendall test to determine if there was a statistically significant change in water levels over the period of study. Precipitation data from weather stations were also analyzed by a Seasonal Kendall test to determine trends in precipitation over time.

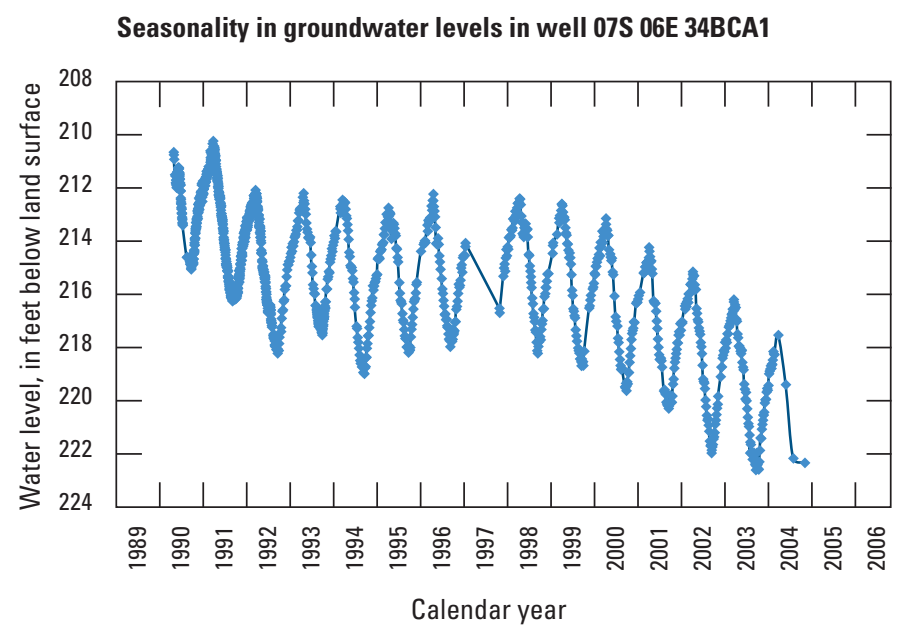

Figure 2. Seasonal fluctuations of water levels from well 07S 06E 34BCA1, typical of seasonal fluctuation in response to groundwater pumping and recharge, Bruneau area, southwestern Idaho.
Regional Kendall tests allow for wells with similar attributes to be analyzed for an overall trend; this study used Regional Kendall tests to calculate trends among five categories of wells with similar attributes (table 3). For a Regional Kendall test, a Kendall test is performed on data from individual wells and results are combined into an overall test to determine a consistent trend among that category of wells. Categories of wells were defined based on well depth, distance from Indian Bathtub Spring, geologic unit (in which the well was completed), regional topographic valley, and water temperature (at the time of well completion [table 3]). There is limited information about some wells, such as completion information, water temperature, and geologic information. This lack of data led to some wells not being categorized and thus excluded from the analysis, resulting in small datasets that gave less power to statistical tests.

Table 3. Categories of wells for Regional Kendall analysis as suggested by U.S. Fish and Wildlife Service, March 2010.

[A bbreviations: BLS, below land surface; ${ }^{\circ} \mathrm{C}$, degrees Celsius; <, less than; >, greater than]

\begin{tabular}{c}
\hline Categories \\
\hline Well depth (in feet BLS) \\
\hline $0-200$ \\
$201-500$ \\
$501-1,000$ \\
$1,001-1,500$ \\
$1,501-2,000$ \\
\hline Distance from Indian Bathtub Spring (in miles) \\
\hline$<1$ \\
$1.01-3$ \\
$3.01-10$ \\
$10.01-15$ \\
$15.01-20$ \\
\hline Geologic unit \\
\hline Idaho Group \\
Idavada Group \\
Banbury Group \\
\hline Regional topographic valley \\
\hline Bruneau Valley \\
Sugar Valley \\
Little Valley \\
\hline Temperature $\left({ }^{\circ} \mathrm{C}\right)$ \\
$<30$ \\
$30-40$ \\
$>40.01$ \\
\hline
\end{tabular}




\section{Data Selection}

Records of measurements from monitoring wells located throughout the Bruneau study area provide water-level data from various aquifers from 1950 to present (2012). Multiple agencies recorded water levels in wells throughout the study area for various purposes. For this study, 22 monitoring wells in the Bruneau study area were selected for statistical analysis (table 4) based on length and consistency of record. These wells were measured by the USGS, private consultants, or IDWR. Water-level data were obtained from the USGS National Water Information System (NWIS) (U.S. Geological Survey, 2011) and the IDWR groundwater-level database hydro.online (Idaho Department of Water Resources, 2010); information about well completion is available in drillers' logs archived by IDWR (2012). Monitoring wells penetrate both the unconfined alluvium and geothermal (volcanic-rock and sedimentary-rock) aquifers. Therefore, observed trends in monitoring wells may not reflect water levels from only the geothermal system.

Precipitation data were obtained from two NWS weather stations representing the area-Bruneau and Mountain City. These weather stations collected rain and snow precipitation data from 1962 to 2009 (Bruneau) and from 1955 to 1999 (Mountain City). The Mountain City, Nevada, station is topographically upgradient of the Bruneau River basin and was used to represent possible recharge [this is representative of the upstream area defined by Berenbrock (1993) that may be a recharge area]. Average annual precipitation over the period of record ranges from 7.44 in. at Bruneau to 13.53 in. at Mountain City (U.S. Department of Commerce, 2011).

\section{Computation of Tests}

A DOS executable computer program for the Kendall trend tests developed by Helsel and others (2006) was used to perform the Kendall tests. Test statistics generated by this program included Kendall's tau, the Kendall test statistic $S$, and the $p$-value for significance of trend. For examples of input or output files for the program, see Helsel and others (2006).

\section{Refining Data for Analysis}

Many measurements were available from the years of observation; these data were edited for input into the computer program for the Kendall family of trend tests (Helsel and others, 2006). To create a two-season seasonal Kendall-test, the program required each calendar year to contain two values representing water levels from the irrigation and non-irrigation seasons. One data point was selected from each season to represent seasonal water levels; this data point was automatically generated by the DOS executable computer program by selecting the median seasonal value from a list of water level measurements and decimal dates.

To verify that two-season seasonal Kendall tests were appropriate, four-season Kendall-test analyses also were run, but the tests were not as statistically robust (as evidenced by higher $p$-values) as two-season Kendall tests. Seasonal values also were manually selected and input into the program and results similar to the automated tests were generated.

Regional Kendall tests were performed on data from wells grouped into each of the five categories described in table 3 to determine trends in water levels over time. Program input required one value per year for each well to represent annual water levels. The selected value was chosen to represent conditions as unaffected by irrigation pumping as possible. Due to the varied amount of available data from each well and desire to not produce error or bias by calculating an aggregate value, a water level from early March (before the start of the irrigation season) was selected as the representative value from each well. 


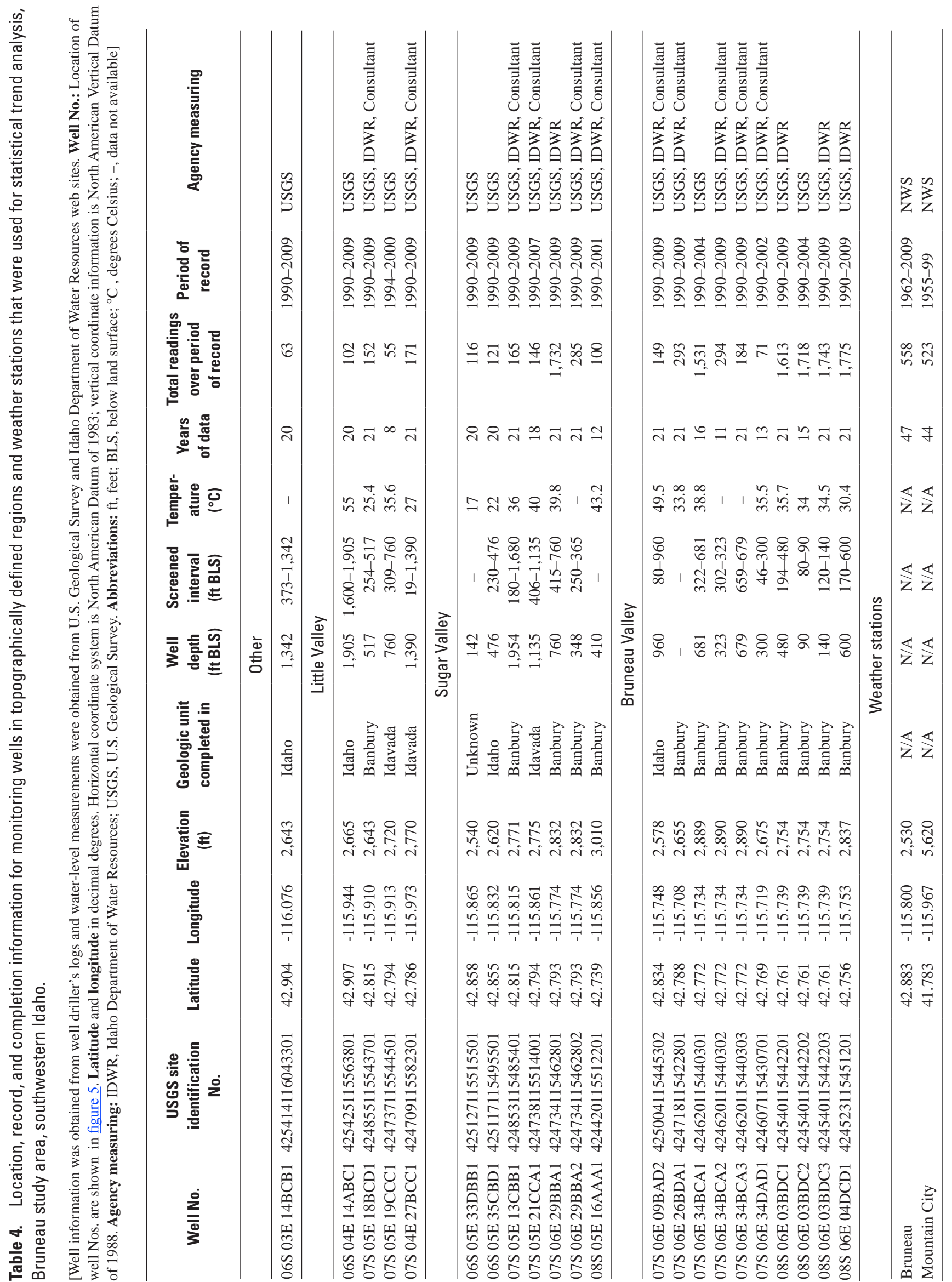




\section{Estimated Drawdown}

The Theis equation and the principle of superposition of solutions were used to estimate drawdown and recovery. Effects of drawdown from pumping and recovery of a well after pumping has ceased can be projected on a specified area using the superposition principle (Reilly and others, 1987). Analytical solutions describe the response of an aquifer in an idealized representation of the real world. Therefore, the drawdown calculations generated by analytical methods must be viewed as idealized estimates of the response of an aquifer to assumed parameters.

Various pumping rates and times were used to estimate the effects of pumping on groundwater levels. Published hydraulic information was used to calculate the timing and magnitude of drawdown conditions from continuous groundwater pumping. Drawdown, as calculated by the Theis equation, is affected by the amount of water being removed from an aquifer, the permeability of the aquifer, and the ability of the aquifer to store or release water. Such hydraulic parameters were determined from single-well (well-performance and slug) tests and multiple-well aquifer tests.

Groundwater movement in an aquifer is controlled by hydraulic parameters. The measure of the water-transmitting characteristic of a material, termed the hydraulic conductivity, is controlled by the size and arrangement of water-transmitting pores or fractures, as well as the dynamic characteristics of water itself (Heath, 1987). Transmissivity is the hydraulic conductivity of an aquifer multiplied by the saturated thickness (or vertical extent of water-bearing material) of an aquifer (Heath, 1987). Storativity (or storage coefficient) is the volume of water that an aquifer releases from storage per unit of surface area per unit decrease in hydraulic head (Freeze and Cherry, 1979). The Theis equation allows for the calculation of drawdown from a pumping well if flow, transmissivity, and storativity are known. The range of values used to estimate idealized drawdown is presented in table $\underline{5}$. Because the analytical approach used in this investigation cannot incorporate variations in hydraulic parameters, a range of values were taken from the literature and analyzed for different combinations of flow, transmissivity, and storativity.

The Theis equation assumes an idealized version of an aquifer. This idealized aquifer is a confined aquifer, or an aquifer that is bounded above and below by impermeable beds and is completely saturated (Heath, 1987). The idealized aquifer has the same hydraulic parameters throughout, properties referred to as homogeneity and isotropy (Freeze and Cherry, 1979). All calculations made here incorporate these assumptions; it is likely these assumptions do not reflect real-world conditions.

\section{Values Used in Drawdown Estimation}

The Theis equation uses values of storativity, transmissivity, and flow (rate of groundwater pumping) to calculate drawdown effects. Values of hydraulic parameters were taken from Berenbrock (1993); they encompass the full range of storativity and transmissivity values found in sedimentary-rock and volcanic-rock aquifers (table 5). The sedimentary-rock and volcanic-rock aquifers had differing ranges of hydraulic parameters; analyses were made of both types of aquifer to represent a range of possible conditions that may be found in the study area. Groundwater from the unconfined alluvium (cold-water aquifer) was not included in the analysis because of its assumed lack of influence on geothermal seeps and springs. Transmissivity values included the span of values calculated by two different methods used by Berenbrock (1993, table 3) (where transmissivity was calculated by multiplying specific capacity by 267 or by multiplying thickness of the aquifer by hydraulic conductivity). Because of the large range of values, the geometric means of transmissivity and storativity values were used as a mid-range value between the high and low values. The geometric mean was selected to prevent extreme numbers from skewing the estimate of the mean (Helsel and Hirsch, 2002).

Table 5. Range of hydraulic parameters used in this study, Bruneau study area, southwestern Idaho.

[Transmissivity and storativity values taken from Berenbrock (1993, table 3). Flow was calculated as described in text. A bbreviations: $\mathrm{ft}^{2} / \mathrm{d}$, foot squared per day; acre-ft/yr, acre-feet per year; -, data not available]

\begin{tabular}{|c|c|c|c|c|c|}
\hline Parameter & $\begin{array}{c}\text { Low } \\
\text { value }\end{array}$ & Well & $\begin{array}{l}\text { High } \\
\text { value }\end{array}$ & Well & $\begin{array}{c}\text { Geometric } \\
\text { mean }\end{array}$ \\
\hline \multicolumn{6}{|c|}{ Sedimentary aquifers } \\
\hline Transmissivity ( $T$, in $\mathrm{ft}^{2} / \mathrm{d}$ ) & 300 & 6S 5E 23DDD1 & 33,000 & 6S 4E 35ACC1 & 3,730 \\
\hline Flow ( $Q$, in acre-ft/yr) & 100 & - & 610 & - & 250 \\
\hline Storativity ( $S$, dimensionless) & 0.0004 & - & 0.002 & - & 0.0009 \\
\hline \multicolumn{6}{|c|}{ Volcanic aquifers } \\
\hline Transmissivity ( $T$, in $\left.\mathrm{ft}^{2} / \mathrm{d}\right)$ & 300 & 11S 7E 25ACA1 & 980,000 & 7S 4E 23CBB1 & 13,000 \\
\hline Flow ( $Q$, in acre-ft/yr) & 100 & - & 610 & - & 250 \\
\hline Storativity (S, dimensionless) & 0.001 & - & 0.003 & - & 0.002 \\
\hline
\end{tabular}




\section{Historical and Potential Groundwater Drawdown in the Bruneau Area, Owyhee County, Southwestern Idaho}

Due to uncertainty about aquifer properties and geometry in the Bruneau study area, the drawdowns calculated in this report should be considered estimates. It was assumed that the range of published values in Berenbrock (1993) represents the range of values present in the Bruneau study area.

Flow was calculated as the amount of estimated annual groundwater pumpage based on irrigation demand using a multi-step process. Crop types were identified from land-cover maps (National Agricultural Statistics Service, 2011) and it was assumed that pumpage was equivalent to evapotranspiration and rates were estimated for each crop using the ETIdaho web site (Allen and Robison, 2009) which incorporates the standardized Penman-Monteith reference equation at a number of weather stations throughout Idaho. For this analysis, calculations were made for 2009 conditions observed at the Bruneau NWS station.

Irrigated crops in the study area identified by land-cover data include dry beans, alfalfa, field corn, grain, and grass pasture. Evapotranspiration rates ranged from 9.92 to 58.15 inches per year (in/yr). The volume of evapotranspiration (in acre-ft/yr) was calculated by multiplying irrigated acreage by evapotranspiration rate. Calculations assumed that each well would supply a 0.25 mi long pivot section, irrigating roughly 125 acres, typical of irrigation practices in the area. The resulting values were 100 and 610 acre-ft/yr (table 5). A mid-range flow value was assigned to represent the median value of all evapotranspiration estimates (250 acre-ft/yr). All calculations are rounded to two significant figures.

\section{Analysis of Data}

Three locations were used to represent the habitat for the Bruneau hot springsnail (fig. 3). Two points along the Bruneau River represented the upstream (HS2) and downstream (HS1) limit of geothermal seeps and springs and one location was at Indian Bathtub Spring (HS3), located along Hot Creek (table 6). All estimates are applicable to any of these three points.
A spreadsheet was used to calculate drawdown using the Theis equation and combinations of hydraulic parameters in table 5 (Halford, 2005). Extent of groundwater drawdown was calculated by assuming a single well was pumping. The distance drawdown value generated represents the radial distance of the cone of depression given the assumptions used.

This program uses the Theis equation (1), rearranged to solve for s:

$$
s=(Q / 4 \pi T) W(u)
$$

where:

$$
\begin{aligned}
& S=\text { drawdown (change in hydraulic head at a point } \\
& \text { since the beginning of pumping), } \\
& Q=\text { flow, or the discharge rate for a pumping well } \\
& \text { (at the origin), } \\
& T=\text { transmissivity of the aquifer, } \\
& W(u)=\text { well function that is derived from the location } \\
& \text { where the Theis curve meets } 1 / u \text {, where } u \text { is } \\
& \text { calculated using the following equation }(2) \text { : }
\end{aligned}
$$

$$
u=\left(r^{2 s}\right) / 4 T t
$$

where:

$$
\begin{aligned}
& u=\text { dimensionless time parameter, } \\
& r=\text { radial distance from the pumping well to } \\
& \text { the point where drawdown is observed, } \\
& T=\text { transmissivity of the aquifer, } \\
& t=\text { time since pumping began. }
\end{aligned}
$$




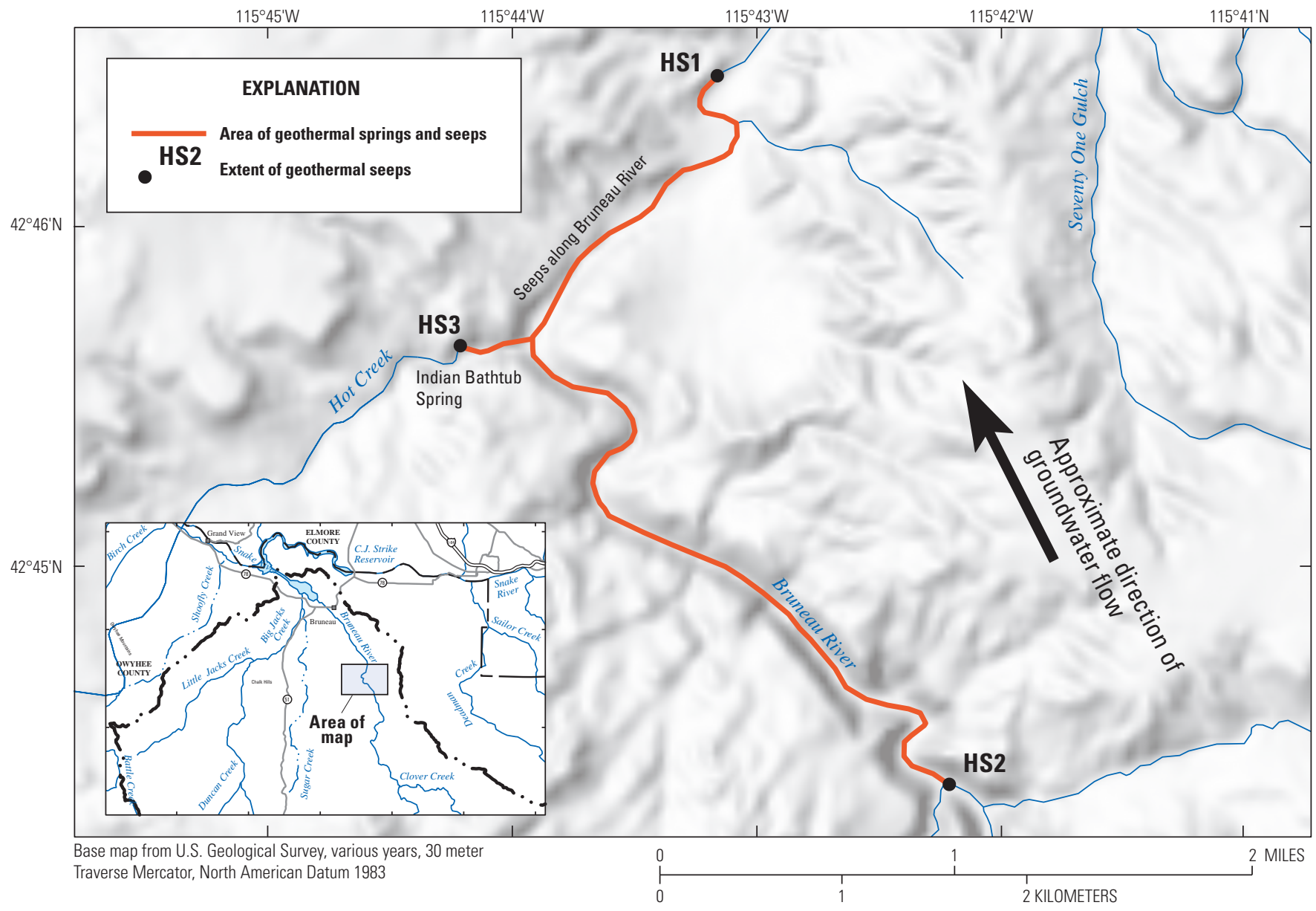

Figure 3. Three locations representing the geothermal inflow stretch along the Bruneau River, southwestern Idaho. Two locations represent the upstream (HS2) and downstream (HS1) limit of geothermal seeps and springs and one location is at the Indian Bathtub Spring (HS3), located along Hot Creek.

Table 6. Extent of geothermal seeps and springs along the Bruneau River, southwestern Idaho.

[Latitude and longitude in decimal degrees. Coordinate system: North American Datum of 1983. Actual locations of geothermal seeps as reported by U.S. Fish and Wildlife Service]

\begin{tabular}{lccc}
\hline \multicolumn{1}{c}{ Name } & Site name & Latitude & Longitude \\
\hline Downstream extent of geothermal seeps & HS1 & 42.776 & -115.718 \\
Beginning of geothermal seeps & HS2 & 42.741 & -115.702 \\
Indian Bathtub Spring & HS3 & 42.762 & -115.734 \\
\hline
\end{tabular}




\section{Trends in Historical Drawdown}

A measure of the level of significance of a statistical test, also known as a $p$-value, was generated by the Kendall tests and used to determine the presence or absence of trends in groundwater levels. A $p$-value is a result of a test on the null hypothesis; in this study examining groundwater levels, the null hypothesis was that groundwater levels did not change over time. If the data failed to support the null hypothesis, the $p$-value generated by the test was small and the null hypothesis was rejected (Ott and Longnecker, 2001). The lower the $p$-value was, the more significant the trend. Tests generating small $p$-values $(\mathrm{p}<0.10)$ indicate a significant trend in groundwater levels over the period of assessment. A $p$-value of less than 0.10 indicates with at least 90 percent certainty that the null hypothesis is rejected, or that there is a significant trend in the data.

\section{Seasonal Kendall Results}

Results from Seasonal Kendall tests from 22 wells are presented in table 7 . The results show slopes (describing the overall trend) and $p$-values (including those seasonally adjusted) for both automated tests. Seven wells have a period of record of less than 20 years (table 4); such limited data give less power to the tests on these wells and limits the amount of information that can be derived about long-term trends.

Seasonal Kendall tests indicated that most wells showed statistically significant downward trends in groundwater levels. The $p$-values for statistically significant Seasonal Kendall tests ranged from $<0.001$ to 0.081 . Seasonal Kendall analyses of statistically significant individual wells generated positive slopes, indicating that these wells experienced statistically significant declining water levels during the period of record (fig. 4). Statistically significant tests had slopes ranging from 0.21 to 1.0 in individual wells.

Wells with seasonally adjusted $p$-values greater than 0.10 indicate that water levels did not undergo a significant monotonic change over time. Four wells (06S 04E 14ABC1, 07S 05E 18BCD1, 07S 05E 19CCC1, and 07S 06E 09BAD2) had adjusted $p$-values that were greater than the specified $p$-value limit (0.10) and were not considered to show a significant trend over time. Wells without a significant trend in water levels could indicate a relatively constant water level or exhibit too much variation to discern a trend.
Seasonal Kendall tests for the Bruneau and Mountain City weather station precipitation data generated seasonally adjusted $p$-values of 0.737 and 0.258 , indicating that no significant trend in precipitation was apparent over the time period examined. A comparison between trends indicate that declines in groundwater levels are not linked with recent precipitation. Historical trends in precipitation prior to the period of record could not be determined and their effects on groundwater could not be accounted for.

Table 7. Results from Seasonal Kendall trend analysis of water levels in monitoring wells and weather stations, Bruneau study area, southwestern Idaho.

[Seasonal Kendall trend analysis performed on DOS executable program. Numbers in bold represent a $p$-value greater than 0.10 ; slopes generated from these tests are not statistically significant. Positive slopes indicate increasing depth to water. A bbreviations: USGS, U.S. Geological Survey; ft/yr, feet per year]

\begin{tabular}{|c|c|c|c|}
\hline \multirow[b]{2}{*}{$\begin{array}{c}\text { USGS site } \\
\text { identification } \\
\text { No. }\end{array}$} & \multicolumn{3}{|c|}{ Seasonal Kendall test: Automated } \\
\hline & $\begin{array}{c}\text { Trend slope } \\
\text { (ft/yr) }\end{array}$ & $p$-value & $\begin{array}{l}\text { Adjusted } \\
p \text {-value } \\
\text { (seasonally } \\
\text { adjusted) }\end{array}$ \\
\hline 08S 05E 16AAA1 & 0.49 & 0.002 & 0.012 \\
\hline 08S 06E 04DCD1 & 0.55 & $<0.001$ & $<0.001$ \\
\hline 08S 06E 03BDC1 & 0.91 & $<0.001$ & $<0.001$ \\
\hline 08S 06E 03BDC2 & 0.40 & $<0.001$ & 0.000 \\
\hline 08S 06E 03BDC3 & 0.32 & $<0.001$ & $<0.001$ \\
\hline 07S 06E 34DAD1 & 0.38 & 0.000 & 0.002 \\
\hline 07S 06E 34BCA1 & 0.44 & $<0.001$ & 0.000 \\
\hline 07S 06E 34BCA2 & 0.29 & 0.057 & 0.048 \\
\hline 07S 06E 34BCA3 & 0.56 & $<0.001$ & $<0.001$ \\
\hline 07S 04E 27BCC1 & 0.51 & 0.000 & 0.000 \\
\hline 07S 06E 26BDA1 & 0.53 & $<0.001$ & $<0.001$ \\
\hline 07S 06E 29BBA1 & 0.56 & $<0.001$ & $<0.001$ \\
\hline 07S 06E 29BBA2 & 0.30 & $<0.001$ & $<0.001$ \\
\hline 07S 05E 19CCC1 & 0.32 & 0.440 & 0.412 \\
\hline 07S 05E 21CCA1 & 0.35 & 0.004 & 0.004 \\
\hline 07S 05E 13CBB1 & 1.01 & $<0.001$ & 0.000 \\
\hline 07S 05E 18BCD1 & -0.22 & 0.996 & 0.966 \\
\hline 07S 06E 09BAD2 & 0.18 & 0.377 & 0.439 \\
\hline 06S 05E 35CBD1 & 1.10 & 0.113 & 0.047 \\
\hline 06S 05E 33DBB1 & 0.21 & 0.081 & 0.051 \\
\hline 06S 03E 14BCB1 & 0.85 & 0.000 & 0.003 \\
\hline 06S 04E 14ABC1 & 0.75 & 0.568 & 0.554 \\
\hline \multicolumn{4}{|l|}{ Weather stations } \\
\hline Bruneau & 0.00 & 0.709 & 0.737 \\
\hline Mountain City & 0.00 & 0.253 & 0.258 \\
\hline
\end{tabular}




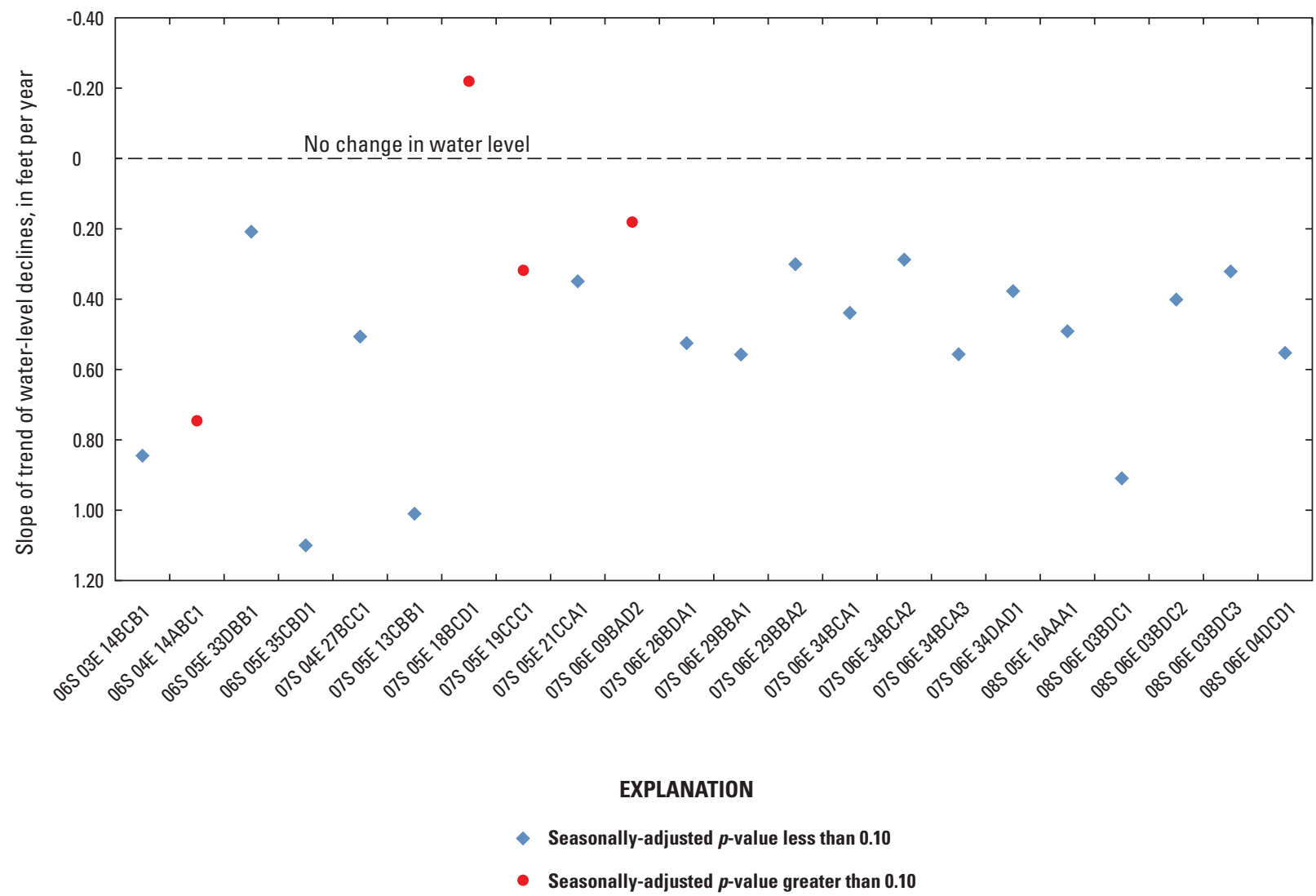

Figure 4. Slopes of trends of groundwater decline by monitoring well, generated by Seasonal Kendall test, Bruneau study area, southwestern Idaho.

\section{Regional Kendall Results}

Regional Kendall tests were performed to determine if one particular group of wells appeared to have significant water-level declines. Wells were grouped by depth, distance from Indian Bathtub Spring, geologic unit, and water temperature (table 3). In addition, wells were assigned to regional topographic valleys (fig. 5) and divided into the Bruneau, Sugar, and Little Valleys.

All Regional Kendall tests yielded $p$-values less than 0.10 and indicated a significant change in slope over time; slope values varied by category (table 8). Groups categorized by distance from the Indian Bathtub Spring generated slopes that ranged from 0.37 to $0.5 \mathrm{ft} / \mathrm{yr}$ and did not seem to exhibit any discernible pattern based on distance from the spring. Wells categorized by geologic unit had relatively similar slopes (ranging from $0.45 \mathrm{ft} / \mathrm{yr}$ in the Banbury Basalt to $0.56 \mathrm{ft} / \mathrm{yr}$ in the Idaho Group). Wells grouped by water temperature had slopes from 0.28 to $0.48 \mathrm{ft} / \mathrm{yr}$ and did not indicate a pattern of one-directional change with increasing temperature gradient. Water temperature was measured at the time of drilling and may represent water from the unconfined alluvium, geothermal aquifer, or a mix of both due to long screen lengths. The slopes of wells categorized by regional topographic valley ranged from $0.35 \mathrm{ft} / \mathrm{yr}$ in Sugar Valley to $0.51 \mathrm{ft} / \mathrm{yr}$ in Little Valley and did not show a significantly larger slope than the Bruneau Valley (0.48 ft/yr).

Perhaps the most informative of the Regional Kendall tests is the test by depth (fig. 6). Slopes of the overall trend increased with depth from $0.27 \mathrm{ft} / \mathrm{yr}$ (in the $0-200 \mathrm{ft}$ range) to $0.62 \mathrm{ft} / \mathrm{yr}$ (in the 1,501-2,000 ft range). An increase of slope with increasing well depth indicates that water-level decreases are more apparent as completion depth increases. This may be due to small sample size (only one well in the $501-1,000 \mathrm{ft}$ and 1,501-2,000 ft categories), but it may indicate an actual trend with depth. Decreases in water level may be most evident in deep wells due to the limited amount of recharge affecting deep wells or other factors that influence the deep parts of the regional aquifer. 


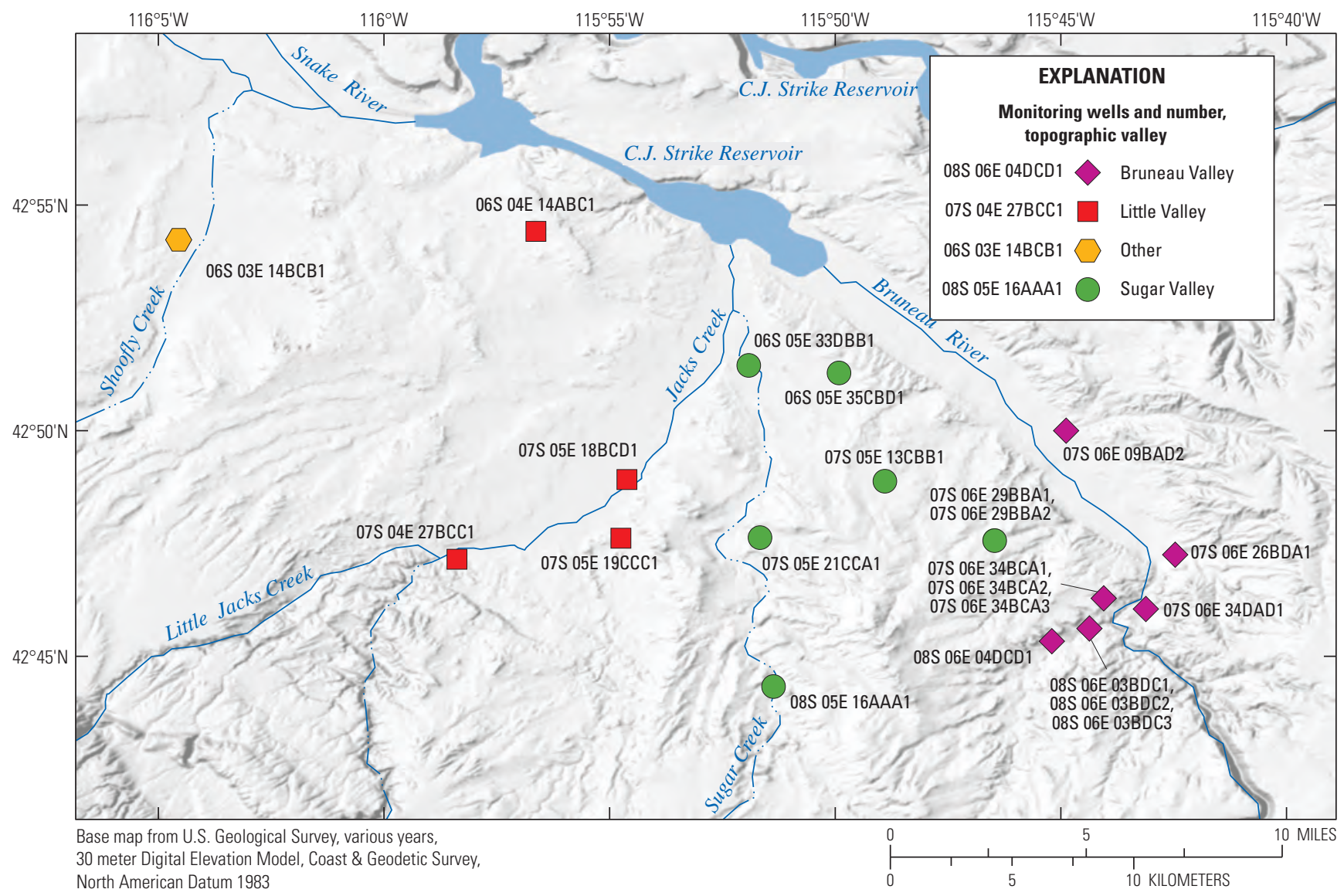

Figure 5. Map showing groups of monitoring wells by regional topographic valley, Bruneau study area, southwestern Idaho.

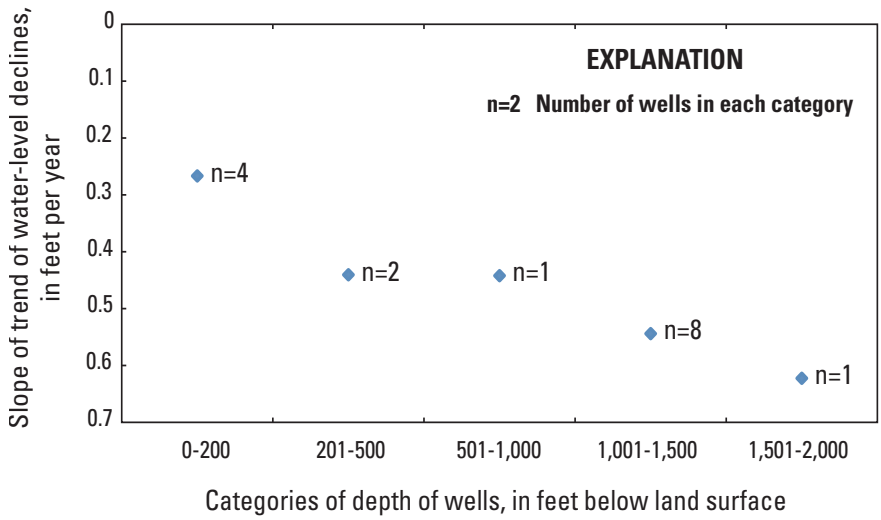

Figure 6. Slopes of trends of groundwater decline as calculated by the Regional Kendall test by depth of wells, Bruneau study area, southwestern Idaho. 
Table 8. Results from Regional Kendall trend analyses of water levels by categories, Bruneau study area, southwestern Idaho.

[Seasonal Kendall trend analysis run on DOS executable program. No $p$-value was greater than 0.10 . A bbreviations: $\mathrm{ft} / \mathrm{yr}$, feet per year; ${ }^{\circ} \mathrm{C}$, degrees Celsus; BLS, below land surface, <, less than; >, greater than]

\begin{tabular}{|c|c|c|c|}
\hline $\begin{array}{l}\text { Category } \\
\text { of wells }\end{array}$ & $\begin{array}{c}\text { Slope } \\
\text { (drawdown } \\
\text { in } \mathrm{ft} / \mathrm{yr} \text { ) }\end{array}$ & $p$-value & $\begin{array}{l}\text { Number of } \\
\text { wells in each } \\
\text { catetory } \\
\text { (n) }\end{array}$ \\
\hline \multicolumn{4}{|c|}{ Completion depth (in feet BLS) } \\
\hline $0-200$ & 0.27 & 0.0000 & 4 \\
\hline $200-500$ & 0.44 & 0.0000 & 2 \\
\hline $500-1,000$ & 0.44 & 0.0000 & 1 \\
\hline $1,000-1,500$ & 0.54 & 0.0000 & 8 \\
\hline $1,500-2,000$ & 0.62 & 0.0339 & 1 \\
\hline \multicolumn{4}{|c|}{ Distance from Indian Bathtub (in miles) } \\
\hline$<1$ & 0.48 & 0.0000 & 1 \\
\hline $1-3$ & 0.37 & 0.0000 & 2 \\
\hline $3-10$ & 0.50 & 0.0000 & 3 \\
\hline $10-15$ & 0.38 & 0.0000 & 5 \\
\hline $15-20$ & 0.48 & 0.0266 & 1 \\
\hline \multicolumn{4}{|l|}{ Geologic unit } \\
\hline Idaho & 0.56 & 0.0042 & 2 \\
\hline Idavada & 0.41 & 0.0000 & 5 \\
\hline Banbury & 0.45 & 0.0000 & 7 \\
\hline \multicolumn{4}{|c|}{ Regional topographic valley } \\
\hline Bruneau & 0.48 & 0.0000 & 1 \\
\hline Sugar & 0.35 & 0.0000 & 3 \\
\hline Little & 0.51 & 0.0002 & 9 \\
\hline \multicolumn{4}{|c|}{ Temperature $\left({ }^{\circ} \mathrm{C}\right)$} \\
\hline$<30$ & 0.45 & 0.0000 & 5 \\
\hline $30-40$ & 0.48 & 0.0000 & 6 \\
\hline$>40$ & 0.28 & 0.0147 & 3 \\
\hline
\end{tabular}

\section{Statistically Significant Water Level Decreases in the Bruneau Study Area}

The majority of results from the Seasonal Kendall and Regional Kendall tests indicate that groundwater in monitoring wells showed statistically significant changes in water levels during the period of record. The overall trend of significant water-level decline ranged from 0.21 to $1.0 \mathrm{ft} / \mathrm{yr}$ during the study period. Significant declines in water levels may be a regional trend that is apparent throughout the Bruneau study area. This would confirm the results published by McVay (2012), indicating that on average, wells in the Grand ViewBruneau Groundwater Management Area exhibit water level declines. However, not all monitoring wells used in this study were completed in the geothermal aquifer. Therefore, the results of this study indicate increasing depth to water in both the geothermal aquifers and unconfined alluvium.

\section{Factors not Accounted for in Statistical Analysis}

These statistical tests determined general drawdown trends; however, there was no attempt to correlate the effects due to pumping, land-use change, and other variables that could be impacting water levels in the Bruneau study area. Groundwater withdrawals for irrigation are most likely a significant contributor to water-level declines. Historical pumping estimates are available in Berenbrock (1993). However, not enough information is available to determine the effect of pumping on groundwater levels in specific monitoring wells to incorporate into this statistical analysis. Analysis of data on regional pumping histories, changes in land use, and drawdown relations between pumping wells and monitoring wells could produce a more powerful statistical analysis of regional trends in the Bruneau study area.

\section{Estimated Drawdown}

Drawdown was estimated for wells completed in the sedimentary-rock (table 9) and volcanic-rock (table 10) aquifers. Results show the radial distance at which drawdown (or recovery) of 1 and $5 \mathrm{ft}$ would be detected at a time intervals of $1,5,10$, and 20 years for specified values of transmissivity, storativity, and flow (table 5). Recovery effects may take longer than those of drawdown, depending on recharge conditions.

Drawdown and recovery effects are greatest in estimates of small drawdown increments and with increasing time. After 20 years of pumping from the sedimentary-rock aquifers, $1 \mathrm{ft}$ of drawdown was simulated as much as $65 \mathrm{mi}$ away from the pumping well, assuming a medium transmissivity, the highest flow, and the lowest storativity values. Using different hydraulic parameters (highest transmissivity and lowest flow values), drawdown was less than one foot during the 20-year time period. Estimations projecting drawdown at the same time period range between these values. 
Similarly, results from estimates in the volcanic-rock aquifer also had a large range. A drawdown of $1 \mathrm{ft}$ in the volcanic-rock aquifers was seen after 20 years as far as $29 \mathrm{mi}$ away (assuming the medium transmissivity and storativity values and the highest flow value). Estimations using the highest transmissivity value for the volcanic-rock aquifers showed that $1 \mathrm{ft}$ of drawdown was less than one foot. Using the same time period while varying hydraulic parameters, drawdown estimates fall between these two extreme values.

Different values of hydraulic parameters changes the projected effects of pumping or recovery. According to the Theis equation, an increase in the flow (pumping rate) will proportionately increase the vertical drawdown and lateral extent of the cone of depression. A decrease in the storativity value increases radial groundwater drawdown. An increase in transmissivity value decreases vertical drawdown but the cone of depression increases in radius. Therefore, a decrease in the transmissivity value increases drawdown at the pumping well, making a cone that is deeper with a tighter radius. Because of the way hydraulic parameters interact, sometimes mid-range values of transmissivity may paradoxically produce more drawdown or a greater radius of drawdown than low values of transmissivity.

The closer a well is to a given geothermal seep or spring, the more likely that pumping of the well will affect drawdown or recovery of the aquifer. The shape of a cone of depression demonstrates that drawdown is greater closer to the pumping center. If all Theis assumptions are valid, pumping near the geothermal seeps or springs would have the greatest effect on drawdown in the area.

Table 9. Estimated distance of specified drawdowns and times in the sedimentary-rock aquifers, Bruneau study area, southwestern Idaho.

[Results generated from the Theis equation and associated assumptions. A bbreviations: acre-ft/yr, acre-feet per year; $\mathrm{ft}^{2} / \mathrm{d}$, foot squared per day; -, target drawdown was not achieved in this simulation]

\begin{tabular}{|c|c|c|c|c|c|c|c|c|c|c|}
\hline \multirow{3}{*}{$\begin{array}{c}\text { Flow } \\
\text { (acre-ft/yr) }\end{array}$} & \multirow{3}{*}{$\begin{array}{c}\text { Transmissivity } \\
\left(\mathrm{ft}^{2} / \mathrm{d}\right)\end{array}$} & \multirow{3}{*}{$\begin{array}{c}\text { Storativity } \\
\text { (dimensionless) }\end{array}$} & \multicolumn{4}{|c|}{ 1-foot drawdown } & \multicolumn{4}{|c|}{ 5-foot drawdown } \\
\hline & & & 1 year & 5 years & 10 years & 20 years & 1 year & 5 years & 10 years & 20 years \\
\hline & & & \multicolumn{8}{|c|}{ Distance from pumping well (in miles) } \\
\hline \multirow[t]{9}{*}{100} & 300 & 0.0004 & 5.6 & 12 & 18 & 25 & 2.3 & 5.1 & 7.2 & 10 \\
\hline & 300 & 0.0009 & 3.7 & 8.3 & 12 & 17 & 1.5 & 3.4 & 4.8 & 6.8 \\
\hline & 300 & 0.002 & 2.5 & 5.6 & 7.9 & 11 & 1.0 & 2.3 & 3.2 & 4.5 \\
\hline & 3,730 & 0.0004 & 2.3 & 5.2 & 7.4 & 10 & - & - & - & - \\
\hline & 3,730 & 0.0009 & 1.6 & 3.5 & 4.9 & 7.0 & - & - & - & - \\
\hline & 3,730 & 0.002 & - & - & - & - & - & - & - & - \\
\hline & 33,000 & 0.0004 & - & - & - & - & - & - & - & - \\
\hline & 33,000 & 0.0009 & - & - & - & - & - & - & - & - \\
\hline & 33,000 & 0.002 & - & - & - & - & - & - & - & - \\
\hline \multirow[t]{9}{*}{250} & 300 & 0.0004 & 7.3 & 16 & 23 & 33 & 4.2 & 9.4 & 13 & 19 \\
\hline & 300 & 0.0009 & 4.8 & 11 & 15 & 22 & 2.8 & 6.2 & 8.8 & 12 \\
\hline & 300 & 0.002 & 3.3 & 7.3 & 10 & 15 & 1.9 & 4.2 & 5.9 & 8.4 \\
\hline & 3,730 & 0.0004 & 8.1 & 18 & 25 & 36 & 0.33 & 0.73 & 1.0 & 1.5 \\
\hline & 3,730 & 0.0009 & 5.4 & 12 & 17 & 24 & 0.22 & 0.49 & 0.69 & 0.97 \\
\hline & 3,730 & 0.002 & 3.6 & 8.1 & 11 & 16 & 0.15 & 0.33 & 0.46 & 0.65 \\
\hline & 33,000 & 0.0004 & 0.05 & 0.11 & 0.15 & 0.21 & - & - & - & - \\
\hline & 33,000 & 0.0009 & - & - & - & - & - & - & - & - \\
\hline & 33,000 & 0.002 & 0.02 & 0.05 & 0.07 & 0.09 & - & - & - & - \\
\hline \multirow[t]{9}{*}{610} & 300 & 0.0004 & 8.8 & 20 & 28 & 39 & 6.0 & 13 & 19 & 27 \\
\hline & 300 & 0.0009 & 5.8 & 13 & 18 & 26 & 4.0 & 8.9 & 13 & 18 \\
\hline & 300 & 0.002 & 3.9 & 8.8 & 12 & 18 & 2.7 & 6.0 & 8.4 & 12 \\
\hline & 3,730 & 0.0004 & 15 & 33 & 46 & 65 & 3.3 & 7.5 & 11 & 15 \\
\hline & 3,730 & 0.0009 & 9.7 & 22 & 31 & 44 & 2.2 & 5.0 & 7.1 & 10 \\
\hline & 3,730 & 0.002 & 6.5 & 15 & 21 & 29 & 1.5 & 3.3 & 4.7 & 6.7 \\
\hline & 33,000 & 0.0004 & 2.9 & 6.4 & 9.0 & 13 & - & - & - & - \\
\hline & 33,000 & 0.0009 & 1.9 & 4.3 & 6.0 & 8.5 & - & - & - & - \\
\hline & 33,000 & 0.002 & 1.3 & 2.9 & 4.0 & 5.7 & - & - & - & - \\
\hline
\end{tabular}


Table 10. Estimated distance of specified drawdowns and times in the volcanic-rock aquifers, Bruneau study area, southwestern Idaho.

[Results generated from the Theis equation and associated assumptions. A bbreviations: acre-ft/yr, acre-feet per year; $\mathrm{ft}^{2} / \mathrm{d}$, foot squared per day; -, target drawdown was not achieved in this simulation]

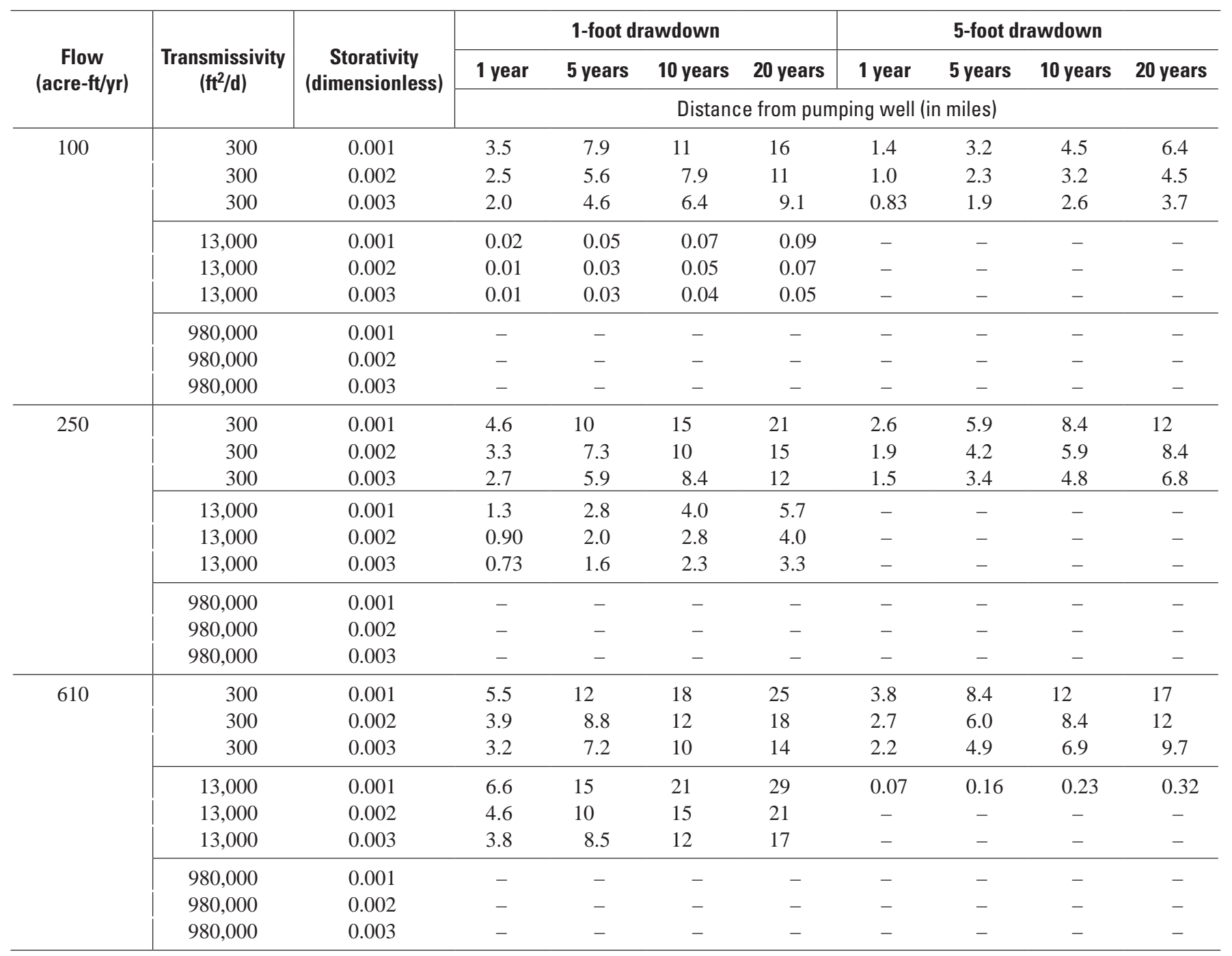




\section{Visualization of Estimated Drawdown}

The distance drawdown calculated by analytical methods represents the radial distance of equal water-table decline; this radius could be used to create a circle with a perimeter showing equal drawdown, representing the cone of depression. Estimates of the effects of a pumping well as pumping and drawdown continue throughout time are shown in figure 7. Drawdown circles centered around Indian Bathtub Spring (HS3) demonstrate the area experiencing $1 \mathrm{ft}$ of drawdown at various times given a set of conditions (pumping from the volcanic-rock aquifers at the highest flow, mid-range transmissivity, and mid-range storativity values). On this map, drawdown is centered on Indian Bathtub Spring; however, circles of drawdown can be placed on any point along the geothermal reach to indicate impacts on that location. Figure 7 implies that if a well is located within the extent of drawdown, it will affect the geothermal system in that area given those hydraulic parameters.

A diagrammatic side-view representation of a pumping well and its cones of depression with increasing time (fig. $\underline{8}$ ) present another way to conceptualize simulations. In this figure, the cones of depression created from different pumping estimates are shown from a cross-sectional side view. As the cone of depression expands with time, $1 \mathrm{ft}$ of drawdown is seen farther from the well and may potentially affect spring flow if the cone of depression intersects geothermal flows.

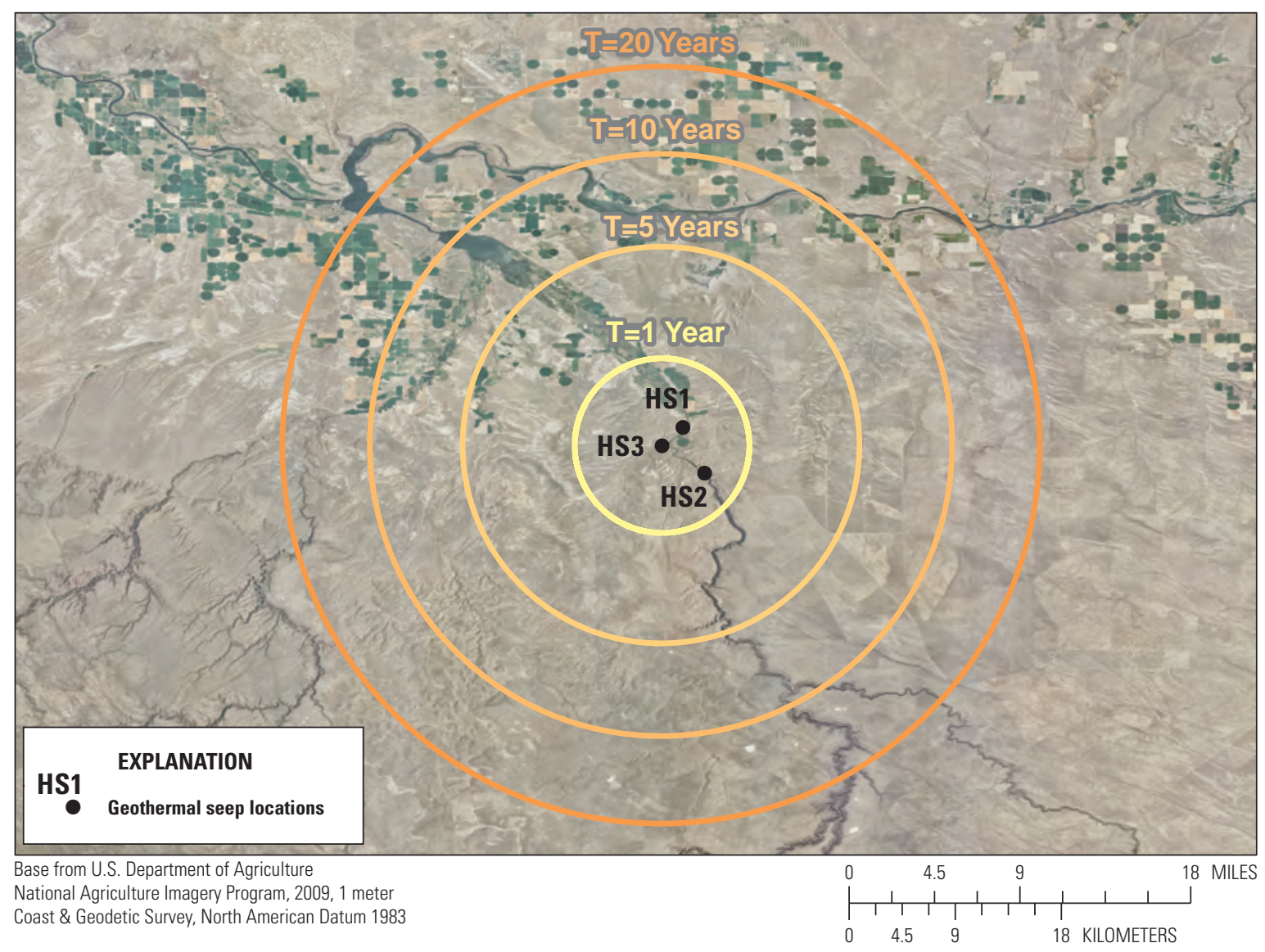

Figure 7. Extent of cone of depression of 1 foot of drawdown with increasing time $(1,5,10$, and 20 years $)$ assuming highest flow, mid-range transmissivity, and highest storativity values in the volcanic-rock aquifers, Bruneau area, southwestern Idaho. Drawdown is centered on Indian Bathtub Spring (HS3). 


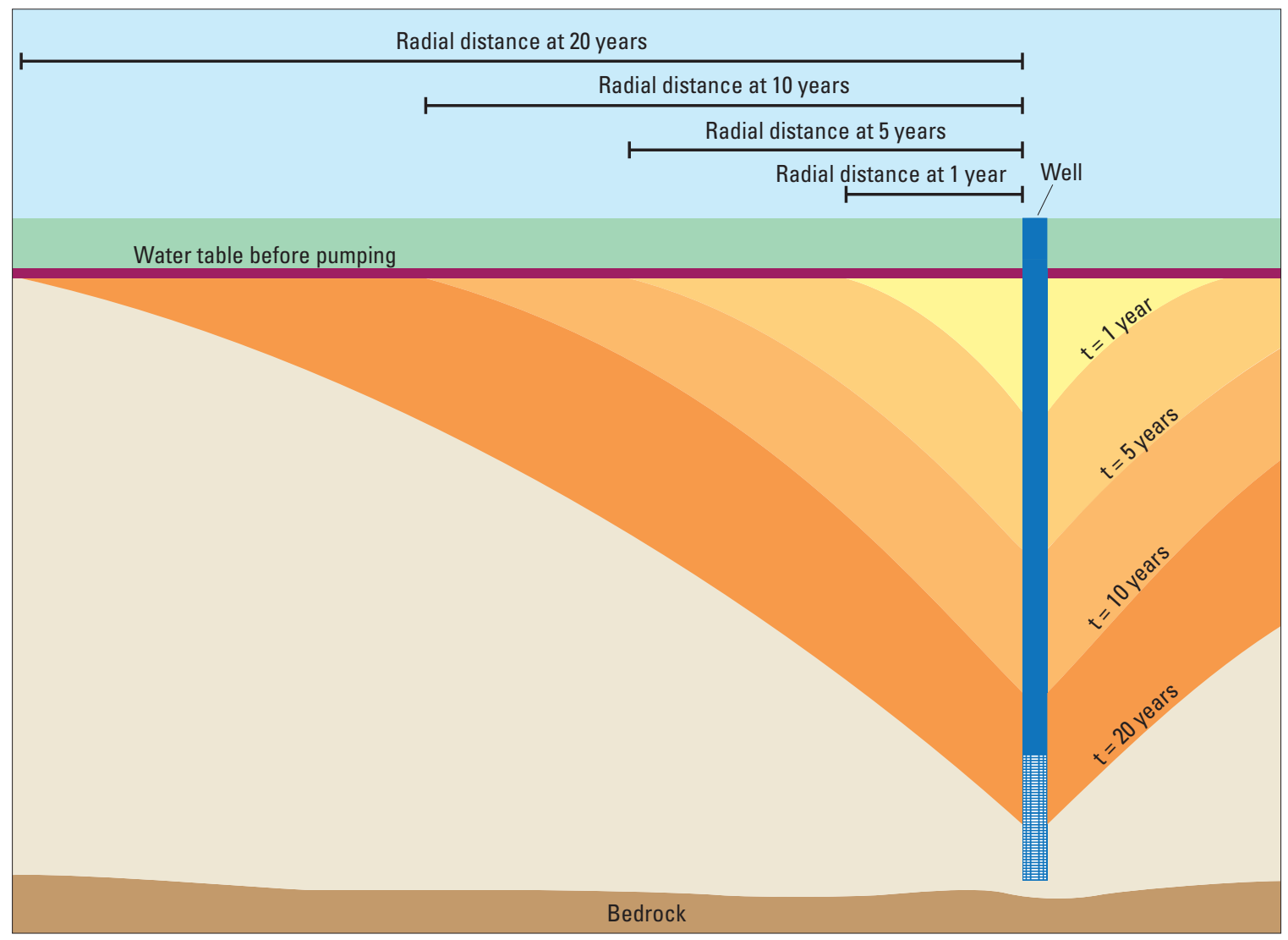

Figure 8. Representation of cones of depression produced by a pumping well. The drawdown caused by continuous pumping increases radially as time progresses.

\section{Assumptions of Analytical Methods}

The estimates presented here incorporate assumptions that may not be valid in the study area. The Theis equation assumes a homogeneous, isotropic aquifer with known hydraulic parameters. In reality, the geothermal aquifer is most likely not homogeneous or isotropic; the range of hydraulic parameters used in this study indicate that the aquifers probably have varying characteristics throughout. In addition, calculations assumed a confined, horizontal aquifer of infinite extent. Varying geology and a confining unit of unknown extent may limit the validity of these assumptions on a large scale.

Simplifying assumptions were made for this study. Elevation differences between wells and the geothermal seeps and springs along the Bruneau River were not accounted for, thus estimates assume a flat potentiometric surface. Estimates assumed that pumping did not induce flow from the Bruneau River or Snake River, or account for other forms of recharge. In actuality, recharge has been determined to contribute to the geothermal aquifers (Berenbrock, 1993). Calculations were made for the effects of one pumping well; in reality, many wells in the area are pumping and drawdown may increase with multiple pumping wells. Estimates also assumed unfractured and uniform geology, and did not account for lateral changes in stratigraphy or faults that may affect the aquifer.

Ideally, the assumptions made in this study could be tested by measuring drawdown near a well with known hydraulic parameters. However, there is no location in the study area where a monitoring well is close to a single pumping well. All monitoring wells, and therefore, areas where drawdown could be monitored, are in areas that could potentially be affected by multiple pumping wells. 


\section{Sensitivity Analysis}

To compensate for the unknown hydraulic parameters at the location of a pumping well, drawdown calculations were made using combinations of hydraulic parameters. The range of distance-drawdown values demonstrates how the uncertainty about hydraulic properties in an exact area can generate substantially different drawdown results using the Theis equation. The effect of changing one hydraulic parameter (fig. 9), such as storativity, can be quite large. In figure 9, the aquifer type, flow, transmissivity, time, and amount of drawdown remain constant while only the assumed storativity value changes. The uncertainty associated with such a large range of hydraulic parameters indicates that drawdown may range over an order of magnitude or more from the calculated results.

\section{Suggestions for Further Study}

All calculations in this study were made using existing data. Future studies could benefit from additional data collection and assumption testing. The statistical analysis would be more robust if additional data regarding well completion and water temperature were available. Future studies would benefit by examining more than 20 years of data and by the addition of more monitoring wells to the network, especially near geothermal seeps and springs of interest. The comparison of results from this study with trends from other monitoring wells in the western Snake River Plain may give insight into trends specific to the Bruneau study area.

The estimated drawdown portion of this study was based on many assumptions and more robust results could be achieved with additional knowledge of aquifer properties near the area of interest. A large range of hydraulic parameters and pumping rates generated varying drawdown estimates.

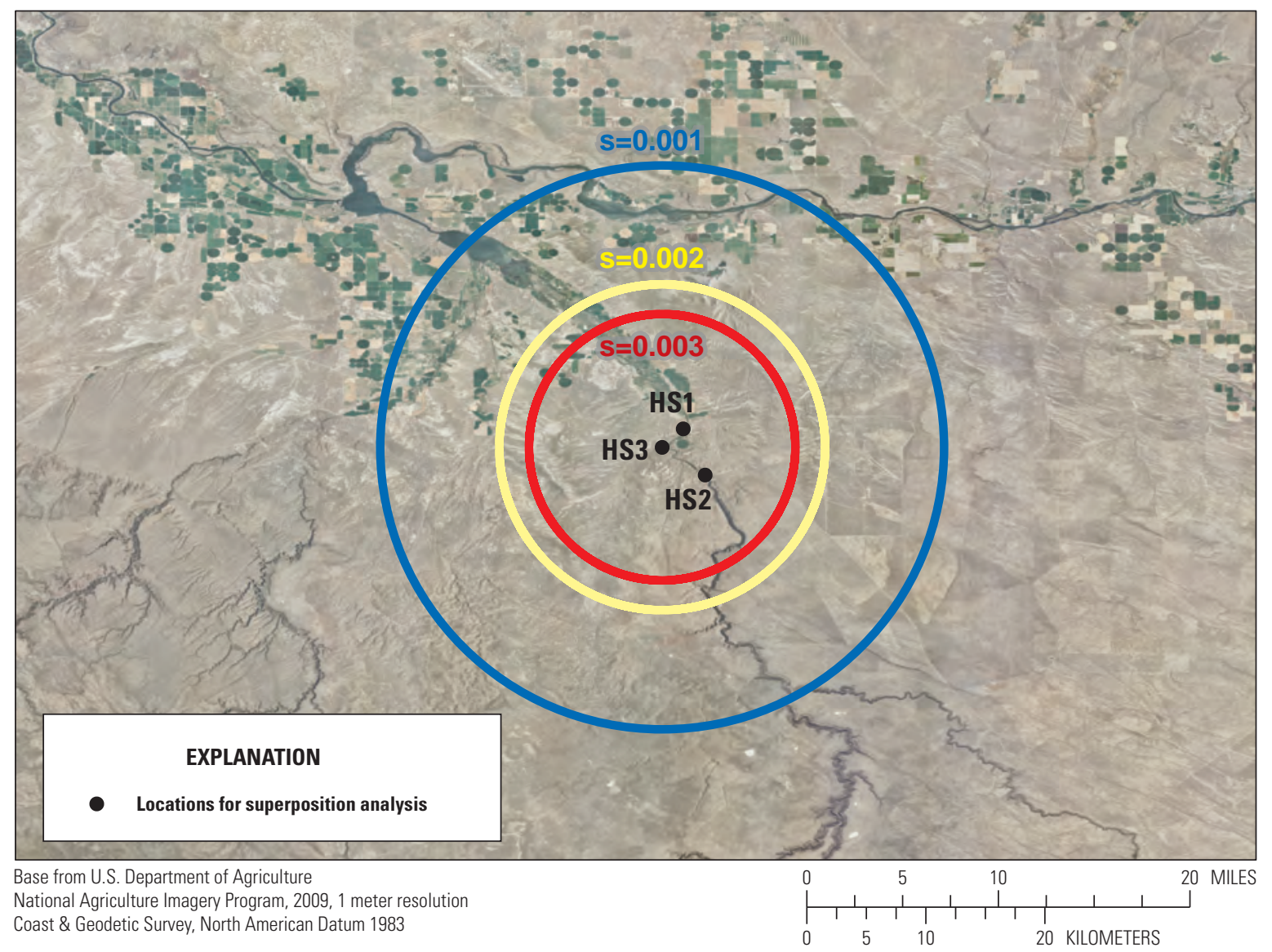

Figure 9. Cones of depression based on different values of storativity. Circles representing the radial distance experiencing $1 \mathrm{ft}$ drawdown in the volcanic-rock aquifers after 5 years of pumping at a highest flow and mid-range transmissivity values, Bruneau area, southwestern Idaho. Drawdown is centered on Indian Bathtub Spring (site HS3). 
The same method of estimating drawdown used in this study could be applied at specific wells to generate better estimates of the effects of conservation efforts; drawdown estimates for a specific well could be generated using the exact hydraulic parameters and pumping information for that particular well.

The assumptions in this study could be applied to a simple numerical model study using the superposition principle. Such a study would require many simplifying assumptions to create a model that has a transmissive layer, correct geometric positions of any surface-water features including springs and streams, and locations of wells of interest. This type of model could calculate capture by specific wells. Previous efforts to model the area were unsuccessful (Berenbrock, 1993) and a simplified model would involve many assumptions.

As conservation efforts move forward, it is important to increase localized water level monitoring and include hydrologic studies in future plans. Closely monitored changes to pumping could generate a greater knowledge of the hydrogeology of the Bruneau study area and effectiveness of conservation efforts. Greater numbers of monitoring wells, especially those installed near wells with decreased pumping, would provide extensive data that could be used in future studies.

\section{Summary and Conclusions}

As part of a two phase study, existing data were used to determine trends in water levels, and groundwater drawdown was estimated to inform conservation efforts aimed at preserving the habitat of the Bruneau hot springsnail. The two components of this study increase the understanding of the possible effects of groundwater withdrawal on geothermal seeps and springs that are vital to the Bruneau hot springsnail habitat. Historical water levels indicate that groundwater levels have significantly decreased in the Brueanu study area. The historical impacts of groundwater drawdown need to be taken into account as conservation efforts seek to maintain the geothermal inflows to the Bruneau River. Both historical and estimated drawdowns imply that water levels, and potentially springs and seeps are affected by pumping.

Water-level data from 22 monitoring wells collected over a 20-year period were analyzed statistically using variations of the Kendall test. Results from a Seasonal Kendall test on individual wells indicated statistically significant ( $p$-value $<0.10$ ) declines in groundwater levels have occurred for
18 of the 22 wells evaluated. Slopes of the trend of waterlevel declines in individual wells ranged from 0.21 to 1.01 feet per year. Water levels from four wells in the study area had $p$-values greater than 0.10 , indicating that they did not experience a significant change in water level over time.

Regional Kendall tests for trends were performed on various categories of wells. Wells were categorized based on well depth, distance from Indian Bathtub Spring, geologic unit, topographical valley, and temperature. The only discernible trend in well categories was seen in wells increasing in depth that had increasing depth to water measurements. All Regional Kendall tests were statistically significant and generated positive slopes, indicating declines in groundwater levels. The general pattern of increasing depth to water throughout the study area as seen in data from monitoring wells indicate that water-level declines may be a regional trend throughout the entire Bruneau study area.

Drawdown, or recovery, was calculated using the Theis equation, a range of hydraulic parameters, and theory of superposition analysis. Estimates were performed for units of the geothermal-bearing aquifers (sedimentary-rock and volcanic-rock). The Theis equation was used to estimate drawdown using different combinations of transmissivity, storativity, and flow (pumping rates). Estimated drawdown varied substantially based on assumptions of hydraulic parameters. For example, by using the mid-range value of transmissivity, the lowest value of storativity, and the highest value of flow, 1 foot of drawdown could be seen in the volcanic-rock aquifer as far as 29 miles away in a 20-year time span. However, by increasing transmissivity to the highest value and using the same values of storativity, flow, and time, estimated results show less than 1 foot of drawdown during the same time period.

A range of values estimating pumping effects at different times and various pumping conditions was generated and presented in two tables. Many assumptions that implied an idealized aquifer were made for these calculations and more accurate estimations of pumping effects could be made with an improved understanding of the aquifer systems. If all Theis assumptions apply, decreasing pumping closer to the geothermal reach would be the most effective groundwater conservation effort. Future studies would benefit from additional collection of water-level measurements. As future conservation efforts are made, it is important to monitor the nearby groundwater system and geothermal seeps and springs to refine hydrological models and to improve understanding of the groundwater system. 


\section{Acknowledgments}

The authors would like to thank Steve Duke of the USFWS for acquiring and sharing Bruneau hot springsnail information. We also would like to thank Keith Halford of the USGS for his assistance with drawdown calculations. Thanks to Stan Leake, Hannah Coy, and Brian Twinning of the USGS for their helpful technical discussions.

\section{References Cited}

Allen, R.G., and Robison, C.W., 2009, Evapotranspiration and Consumptive Irrigation Water Requirements for Idaho: Supplement updating the Time Series through December 2008: Moscow, Idaho, Kimberly Research and Extension Center, University of Idaho, Research Technical Completion Report, accessed May 2, 2012, at http://www.kimberly. uidaho.edu/ETIdaho/

Berenbrock, Charles, 1993, Effects of well discharges on hydraulic heads in and spring discharges from the geothermal aquifer system in the Bruneau area, Owyhee County, southwestern Idaho: U.S. Geological Survey Water-Resources Investigation Report 93-4001, 58 p. (Also available at http://pubs.usgs.gov/wri/1993/4001/report.pdf.)

Blackwell, D.D., 1975, Report on reconnaissance heat flow and geothermal gradient study in north central Owyhee County, Idaho: Berkeley, Calif., GeothermEx, 31 p., accessed March 12, 2012, at http://www.osti.gov/ energycitations/purl.cover.jsp?purl=/894497-EECimg/.

Bureau of Land Management, 2009, Bruneau River-Sheep Creek Wilderness study area, Volume 2-Summary analysis of specific WSA recommendations in Idaho Wilderness study report, p. 233-247, accessed March 12, 2012, at http://www.blm.gov/id/st/en/prog/planning/idaho wilderness_reports/idaho_wilderness_study.html.

Bureau of Reclamation, 2011, AgriMet, The Pacific Northwest cooperative agricultural weather network: Bureau of Reclamation AgriMet network map, accessed March 12, 2012, at http://www.usbr.gov/pn/agrimet/agrimetmap/ agrimap.html.

Critchfield, H.J., 1983, Criteria for classification of major climatic types in modified Köppen system in General climatology (4th ed.): New York, Prentice Hall, 453 p., accessed March 12, 2012, at http://snow.cals.uidaho.edu/ Clim Map/koppen criteria.htm.
Federal Register, 1998, Rules and Regulations, v. 63, no. 116, p. 32,981, accessed March 12, 2012, at http://ecos.fws.gov/ docs/federal register/fr3270.pdf.

Freeze, A.R., and Cherry, J.A., 1979, Groundwater: Englewood Cliffs, New Jersey, Prentice-Hall, 604 p.

Godfrey, Bruce, 2000, Köppen climate classification for the conterminous United States: University of Idaho database, accessed March 12, 2012, at http://snow.ag.uidaho.edu/ Clim_Map/koppen.htm.

Halford, K.J., 2005, Excel for hydrology: U.S. Geological Survey Web site, accessed March 13, 2012, at http://nevada. usgs.gov/tech/excelforhydrology/.

Harrington, H., and Bendixsen, S., 1999, Ground water management areas in Idaho-Overview as of 1998: Idaho Department of Water Resources, Open-File Report, 66 p.

Heath, R.C., 1987, Basic ground-water hydrology: U.S. Geological Survey Water-Supply Paper 2220, 84 p. (Also available at http://pubs.usgs.gov/wsp/wsp2220/.)

Helsel, D.R., and Hirsch, R.M., 2002, Statistical methods in water resources: U.S. Geological Survey Techniques of Water-Resources Investigations, Book 4, Chapter A3, 510 p. (Also available at http://pubs.usgs.gov/twri/twri4a3/html/ pdf new.html.)

Helsel, D.R., Mueller, D.K., and Slack, J.R., 2006, Computer program for the Kendall family of trend tests: U.S. Geological Survey Scientific Investigations Report 2005-5275, 4 p. (Also available at http://pubs.usgs.gov/ $\underline{\text { sir } / 2005 / 5275 / .)}$

Hopper, D., and Burak, G., 2011, Bruneau hot springsnail (Pyrgulopsis bruneauensis) 2010 Range Wide Surveys: U.S. Fish and Wildlife Service, 24 p.

Idaho Department of Water Resources, 2010, hydro.onlinefor ground water level data: Idaho Department of Water Resources database, accessed March 13, 2012, at http:// www.idwr.idaho.gov/hydro.online/gwl/default.html.

Idaho Department of Water Resources, 2011, BruneauGrand View Groundwater Management Area: Idaho Department of Water Resources Web site, accessed March 13, 2012, at http://www.idwr.idaho.gov/WaterInformation/ GroundWaterManagement/GrandViewBruneau/gb gwma. $\underline{\text { htm. }}$. 
Idaho Department of Water Resources, 2012, Well driller reports (logs): Idaho Department of Water Resources database, accessed March 13, 2012, at http://www. idwr.idaho.gov/WaterManagement/WellInformation/ DrillerReports/dr default.htm.

Idaho State Historical Society, 1964, The Owyhee CountryMining, merchants, and industrial agriculture, reference series no. 200: Idaho State Historical Society database, accessed March 13, 2012, at http://history.idaho.gov/ reference-series.

Idaho State Historical Society, 1975, The Owyhee County, Idaho Territory (1863-1890), reference series no. 336: Idaho State Historical Society database, accessed March 13, 2012, at http://history.idaho.gov/reference-series.

Jackson, D.B., 1974, Report on direct current soundings over a geothermal prospect in Bruneau-Grand View Area, Idaho: U.S. Geological Survey Open-File Report 74-420, 43 p. (Also available at http://pubs.er.usgs.gov/publication/ ofr74240.)

Jenks, M.D., Bonnichsen, B., and Godchaux, M.M., 1998, Geologic map of the Grand View-Bruneau area, Owyhee County, Idaho: Idaho Geological Survey Technical Report 98-1, 21 p., 1 map, scale 1:100,000, accessed March 12, 12012, athttp://www.idahogeology.org/Products/ reverselook.asp?switch=title\&value=Geologic Map of the Grand View-Bruneau Area, Owyhee County, Idaho.

Kjelstrom, L.C., 1986, Flow characteristics of the Snake River and water budget for the Snake River Plain, Idaho and eastern Oregon: U.S. Geological Survey Hydrologic Investigations Atlas HA- 680, 2 sheets, scale 1:1,000,000. (Also available at http://pubs.er.usgs.gov/publication/ ha680.)

Littleton, R.T., and Crosthwaite, E.G., 1957, Ground-water geology of the Bruneau-Grand View area: U.S. Geological Survey Water-Supply Paper 708, 70 p. (Also available at http://pubs.usgs.gov/wsp/1460d/report.pdf.)

Malde, H.E., and Powers, H.A., 1962, Upper Cenozoic stratigraphy of western Snake River Plain, Idaho: Geological Society of America Bulletin, v. 73, no. 10, p. 1197-1220.
McGrath C.L., Woods A.J., Omernik, J.M., Bryce, S.A., Edmondson, M., Nesser, J.A., Shelden, J., Crawford, R.C., Comstock, J.A., and Plocher, M.D., 2002, Ecoregions of Idaho (color poster with map, descriptive text, summary tables, and photographs): U.S. Geological Survey Map, scale 1:1,350,000, accessed March 13, 2012, at http://www. epa.gov/wed/pages/ecoregions/id eco.htm.

McVay, Mike, 2012, Summary of groundwater levels in the Grand View-Bruneau Groundwater Monitoring Network — 2011 Update: Idaho Department of Water Resources, Open-File Report, 16 p., accessed March 13, 2012, at http://www.idwr.idaho.gov/WaterInformation/ GroundWaterManagement/GrandViewBruneau/PDFs/G B WaterLevelUpdate2011.pdf.

Moffat, R.L., and Jones, M.L., 1984, Availability and chemistry of ground water on the Bruneau plateau and adjacent eastern plain in Twin Falls County, southcentral Idaho: U.S. Geological Survey Water-Resources Investigations Report 84-4065, 43 p. (Also available at http://pubs.er.usgs.gov/publication/wri844065.)

National Agricultural Statistics Service, 2011, CropScapeCropland data layer, 2010: U.S. Department of Agriculture database, accessed March 13, 2012, at http://nassgeodata. gmu.edu/CropScape/.

Newton, G.D., 1991, Geohydrology of the regional aquifer system, western Snake River Plain, southwestern Idaho: U.S. Geological Survey Professional Paper 1408-G, 52 p., 1 pl. (Also available at http://pubs.er.usgs.gov/publication/ pp1408G.)

Ott, R.L., and Longnecker, M., 2001, An introduction to statistical methods and data analysis ( $5^{\text {th }} \mathrm{ed}$.): Pacific Grove, Calif., Duxbury Publishing, 1,152 p.

Peel, M.C., Finlayson, B.L., and McMahon, T.A., 2007, Updated world map of the Köppen-Geiger climate classification: Hydrology and Earth System Sciences, v. 11, p. 1633-1644, accessed March 12, 2012, at http://www. hydrol-earth-syst-sci.net/11/1633/2007/hess-11-1633-2007. pdf.

Piper, A.M., 1924, Geology and water resources of the Bruneau River basin, Idaho: Moscow, Idaho Bureau of Mines and Geology, Pamphlet 11, 56 p.

Ralston, D.A., and Chapman, S.L., 1969, Ground-water resources of northern Owyhee County, Idaho: Idaho Department of Reclamation, Water Information Bulletin no. 14, 85 p. 
Reilly, T.E., Franke, O.L., and Bennett, G.D., 1987, The principle of superposition and its application in groundwater hydraulics: U.S. Geological Survey Techniques of Water-Resources Investigations, book 3, chap. B6, 28 p. (Also available at http://pubs.usgs.gov/twri/twri3-b6/.)

Stearns, N.D., Stearns, H.T., and Waring, G.A., 1937, Thermal springs in the United States: U.S. Geological Survey WaterSupply Paper 679-B, 200 p. (Also available at http://pubs. er.usgs.gov/publication/pp492.)

Theis, C.V., 1935, The relation between the lowering of the piezometric surface and the rate and duration of discharge of well using ground-water storage: American Geophysical Union Transactions, 16th Annual Meeting, pt. 2, p. 519524.

U.S. Census Bureau, 2011, 2010 demographic profileID-Bruneau CCD: U.S. Census Bureau database, accessed March 13, 2011, at http://www.census.gov/popfinder/

U.S. Department of Commerce, 2011, National Climatic Data Center, accessed March 13, 2011, at http://www.ncdc.noaa. gov.

U.S. Fish and Wildlife Service, 2002, Recovery plan for the Bruneau hot springsnail (Pyrgulopsis bruneauensis): Portland, Oreg., U.S. Fish and Wildlife Service, Region 1, 52 p., accessed March 13, 2012, at http://ecos.fws.gov/docs/ recovery_plan/020930.pdf.

U.S. Fish and Wildlife Service, 2007, Bruneau hot springsnail (Pyrgulopsis bruneauensis) 5-year review, summary and evaluation: Boise, Idaho, U.S. Fish and Wildlife Service, Snake River Fish and Wildlife Office, accessed March 13, 2012, at http://ecos.fws.gov/docs/five_year_review/doc1080. pdf.
U.S. Geological Survey, 2011, National Water Information System (NWISWeb) - Groundwater levels for the nation: U.S. Geological Survey database, accessed March 13, 2012, at http://nwis.waterdata.usgs.gov/usa/nwis/gwlevels.

Western Regional Climate Center, 2011, Western U.S. climate historical summaries: Western Regional Climate Center database, accessed March 13, 2012, at: http://www.wrcc.dri. edu/Climsum.html.

Wood, S.H., and Clemens, D.M., 2002, Geologic and tectonic history of the western Snake River Plain, Idaho and Oregon, in Bonnichsen, B., White, C.M., and McCurry, M., eds., Tectonic and Magmatic Evolution of the Snake River Plain Volcanic Province: Idaho Geological Survey Bulletin 30, p. 69-103.

Young, H.W., and Lewis, R.E., 1982, Hydrology and geochemistry of geothermal ground water in southwestern Idaho and north-central Nevada: U.S. Geological Survey Professional Paper 1044-J, 20 p.

Young, H.W., Jones, H.W., Parlamin, D.J., and Tungate, A.M., 1990, Results of test drilling and hydrologic monitoring in the Indian Bathtub area, Owyhee County, southwestern Idaho, January 1989 through September 1990: U.S. Geological Survey Open-File Report 90-597, 40 p.

Young, H.W., and Whitehead, R.L., 1975, Geothermal investigations in Idaho, Part 2, An evaluation of thermal water in the Bruneau-Grand View area, southwest Idaho, with a section on A reconnaissance audio-magnetic survey, by D.B. Hoover and C.L. Tippens: Idaho Department of Water Resources Bulletin no. 30, 126 p., 5 pls., accessed March 12, 2012, http://www.idwr.idaho.gov/ WaterInformation/Publications/wib/wib30p2-geothermal_ bruneau-grandview.pdf. 
Publishing support provided by the U.S. Geological Survey Publishing Network, Tacoma Publishing Service Center

For more information concerning the research in this report, contact the

Director, Idaho Water Science Center

U.S. Geological Survey

230 Collins Road

Boise, Idaho 83702

http://id.water.usgs.gov

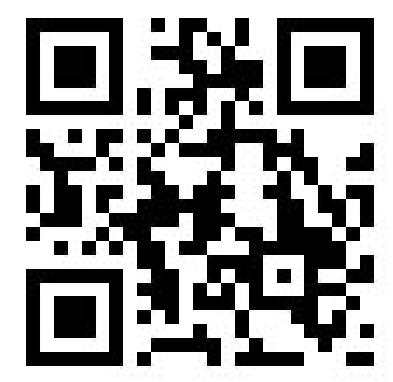


